Çer, E. (2020). Kavram dağarcığının geliştirilmesinde düzeye uygun bir çocuk kitabının etkisi: Bir uygulama örneği. Ana Dili Eğitimi Dergisi, 8(4), 1071-1093.

Ana Dili Eğitimi Dergisi
Journal of Mother Tongue Education
www.anadiliegitimi.com
Geliş/Received: 30.04 .2020 Kabul/Accepted:17.07.2020
Araştırma Makalesi / Research Paper

\title{
Kavram Dağarcığının Geliştirilmesinde Düzeye Uygun Bir Çocuk Kitabının Etkisi: Bir Uygulama Örneği*
}

\author{
Erkan ÇER*
}

Öz

Bu araştırmanın amacı, kavram dağarcığının geliştirilmesinde düzeye uygun bir çocuk kitabının etkisini incelemektir. Bu durum, düzeye uygun çocuk edebiyatı yapıtlarının kavram dağarcığı üzerindeki etkilerini ortaya çıkartabilir. Tek denekli araştırma desenlerinden birisi olan $A B A B$ modelinin uygulandığı bu araştırmanın katılımcısı 24. ay içerisinde uygulama süreci boyunca gözlemlenen bir bebektir. Bu araştırmanın verileri, bebeğin içinde bulunduğu döneme uygun bir biçimde belirli ölçütler, uzman görüşü ve bebeğin ilgisi dikkate alınarak seçilen düzeye uygun bir çocuk kitabından elde edilmiştir. Bu araştırmada, 24. ayda olan bir bebeğin kavram dağarcığının geliştirilmesinde bir çocuk kitabının etkisine yönelik elde edilen veriler betimsel olarak çözümlenmiştir. Araştırma sonucunda, uygulayııının kılavuzluğunda bebeğin düzeye uygun bir kitaba yönelik görsel okuma yapması, onun kavram dağarcığııın artmasına olanak tanımıştır. Bu araştırmadan yola çıkarak sunulacak öneri ise, farklı yaş gruplarında cinsiyet ya da sosyo-ekonomik düzey gibi farklılıklar göz önünde bulundurularak bebeklerin düzeye uygun nitelikli kitaplarla kavram dağarcıklarının ne kadar gelişip gelişmediğini ortaya koyan deneysel araştırmaların yapılmasıdır.

Anahtar Kelimeler: Kavram dağarcığı, düzeye uygunluk, çocuk kitapları, uygulama örneği, bebek

\section{The Effect of a Level-Appropriate Children's Book on the Development of the Concept Vocabulary: An Application Example}

\begin{abstract}
The purpose of this study is to investigate the effect of a level-appropriate children's book on the development of the concept vocabulary. This situation can reveal the effects of level-appropriate works of children's literature on the concept vocabulary. The participant of this study, in which the $A B A B$ model was used, which is one of the single-subject research designs is an infant observed during her 24 months. data of this study were obtained from a children's book which was selected according to the level by taking specific criteria, expert view, and the interests of the infant into consideration. In this study, the data obtained on the effect of a children's book on the development of the conceptual vocabulary of a 24-month-old infant were analyzed descriptively. Findings revealed that the visual reading by the infant for a level-appropriate book under the guidance of the practitioner allowed him to increase his conceptual vocabulary. Based on this research, the suggestion is to conduct experimental research showing whether conceptual vocabulary of babies are developed with level-appropriate books considering the differences such as gender or socio-economic level in different age groups.
\end{abstract}

Keywords: Concept vocabulary, level-appropriateness, children's books, application example, infant.

\footnotetext{
* Doç. Dr., Amasya Üniversitesi, Türkçe ve Sosyal Bilimler Eğitimi Bölümü, Türkçe Eğitimi Anabilim Dalı, erkan.cer@amasya.edu.tr, ORCID: 0000-0003-3589-6604
} 


\section{Giriş}

Kavram, ortak özellikleri kendinde taşıyan bir dizi nesne, varlık ve olguya ilişkin genel nitelikli bir anlam içeren, dilsel kökenli her türlü tasarım, düşünce ya da düşlemin, varlık, nesne ya da oluşun bilişsel imgesidir (Türkiye Bilimler Akademisi, 2011). Kavramlar bireyin bir grup olay, varlık, düşünce ve süreçleri diğer gruplardan ayırt etmesini sağladığı gibi diğer olay, varlık, düşünce ve süreçlerle ilişki kurmasına da katkı sağlar (Senemoğlu, 2011). Bu bakımdan, kavram öğrenmek için bir nesne, varlık, olay ve olgunun tüm özelliklerini ve o nesne, varlık, olay ve olgunun öbür nesne, varlık, olay ve olgularla ilişkilerini ve farkıııklarını bilmek gerekir. Daha açık bir anlatımla, ayırt etmeyi öğrenmeden kavramın öğrenilemeyeceğidir. Ayırt edilen özellik, öbür benzer nesne, varlık, olay ve olgulara genelleyerek kavram edinilmiş olur (Bakırcıoğlu, 2012). Bu durum, kavramlar sayesinde dış dünyanın anlaşılmasına ve onlarla iletişim kurulabilmesine katkı sağlar (Tepebaş ve Haktanır, 2013). Bu yönüyle, kavram tasarımı sürecinde çocukların erken dönemden başlayarak nesnelerin ayırt edici özelliklerini açık ve belirgin bir biçimde ortaya koyan düzeye uygun çocuk edebiyatı yapıtlarıyla karşı karşıya getirilmesi gerekir.

Çocuk edebiyatı, erken çocukluk döneminden başlayıp ergenlik dönemini de kapsayan bir yaşam evresinde, çocukların dil gelişimi ve anlama düzeylerine uygun olarak duygu ve düşünce dünyalarını sanatsal niteliği olan dilsel ve görsel iletilerle zenginleştiren, beğeni düzeylerini yükselten yapıtların genel adıdır (Sever, 2008). Bununla birlikte, çocuk edebiyatı okulöncesi dönem ile çocuğun ergenliğe ulaştığı döneme kadar olan bir zaman diliminde çocuğu yaşama hazırlayan, ona anadilinin güzelliklerini duyumsatan, okuma sevgisi ve alışkanlı̆̆ı kazandıran, onun kavram bilgisine katkı sağlayan ve beğeni düzeyini geliştiren bir edebiyattır (Dilidüzgün, 2004; Norton ve Norton, 2010; Sever, 2013). Bu bakımdan, çocuk edebiyatının kurmaca bir gerçeklik içinde düşsel ve gerçek deneyimlerle çocuğun duyma, düş kurma ve düşünme sorumluluğu alabilmesine, kavram tasarımı sürecini yapılandırmasına, bilme ve tanıma isteğini karşılayabilmesine, duygu ve düşünce dünyasıyla insanı ve yaşamı sezinleyebilmesine, estetik beğeni kazanabilmesine, başarı duygusunu yaşayabilmesine, sosyalleşmesi ve paylaşımcı olabilmesine katkı sağlaması gerekmektedir.

Kavramlar, kendiliğinden bellekte oluşmaz; uyarana gereksinim duyar (Sever, 2008, 2013). Bu bakımdan, erken dönemden başlayarak çocuğun belleğindeki kavram sayısının arttırılması için onun nitelikli ve düzeye uygun kitaplarla buluşturulması gerekir. Çocuğun kavram bilgisinin arttırılması, onun kendini anlatabilmesine olanak tanıdığı gibi yaşamı ve insanı anlamasına da katkı sağlayabilir. Çünkü kavramlar, düşünmenin aracıdır (Senemoğlu, 2011). Bu bakımdan, çocuğun kitapla tanıştığı ve arkadaş olma yolunda ilerlediği 0-6 yaş döneminde, renk ve çizginin çocuğun yaşamında önemli işlevleri vardır. Renk ve çizginin yaratıcı anlatım olanaklarıyla oluşturulan kitaplarla karşı karşıya getirilen çocuklar, gerek bilme, tanıma ve öğrenme isteklerini karşılarlar gerekse dış dünyayla iletişim kurarak bilmedikleri dünyayı sezinlemeye çalışırlar (Sever, 2008). Özellikle bu yaş döneminde bulunan çocuklar, kitapta yer alan resimlere bakarak kavramları görsel nitelikleriyle belleğine yerleştirir. Bu durum, çocuğun görme duyusuyla kavram tasarımı sürecinde yer almasına ve kavramın farklı nitelikleriyle ilgili ilişkilerini alımlamasına olanak sağlar. Bütün bu yönleriyle, çocuğun düzeye uygun nitelikli çocuk edebiyatı yapıtlarıyla kavram bilgisinin sürekli olarak geliştirilmesi, onun duygu ve düşüncelerini etkili bir biçimde anlatabilmesine, iletişim becerilerini geliştirebilmesine, düşünce üretebilmesine, doğru ve amaca uygun bir biçimde konuşabilmesine, algılama ve kavrama düzeyinin artmasına, duyarlık ve estetik deneyim kazanmasına olanak tanımaktadır. Özellikle renk, çizgi ya da sözcüklerin anlatım olanaklarıyla oluşturulmuş edebiyat metinlerinin çocuğun yaşam alanına erken dönemden başlayarak katılması, onun görme ve ve işitme duyusunu anlam oluşturma sürecine katarak kitaplarla kurduğu etkileşim ve iletişim sonucunda edindiği kavramlarla duygu ve düşünce dünyasını geliştirmesine yardımcı olacaktır.

Çocukların bilişsel gelişiminin üçte ikisinin ilk beş yıllık dönemde tamamlanması, erken dönemde bilişsel gelişim sürecinin önemini daha çok ortaya koymaktadır. Çünkü kavramların kazanılması süreci bireyin doğumuyla başlayan bir süreçtir (Tepebaş ve Haktanır, 2013). Bu nedenle, bu dönemde çocuklara verilen uyaranlar, onların gizilgüçlerinin ortaya çıkmasını sağlayabilir. Daha farklı bir anlatımla, bu yıllarda beyin hücreleri arasındaki bağlantılar çok fazla geliştiği için yaşamın ilk aylarında ve yıllarında gelişimin çok hızı bir seyir göstermesi bu dönemin önemini arttırmaktadır. Özellikle bu dönemde çocukta algının keskinleşmesi, el-göz eşgüdümünün gelişmesi, odaklanmanın 
artması, merak ve keşfetme isteğinin en üst düzeyde olması (Yavuzer, 2012; Yörükoğlu, 2016), onların gelişimsel düzeylerine uygun, nitelikli çocuk edebiyatı yapıtlarıyla etkileşim ve iletişim odaklı karşı karşıya getirilmesini zorunlu kılmaktadır. Çünkü çocuklar yaşamın ilk aylarından başlayarak bilme ve tanıma isteği içinde olan canlılardır (Bee ve Boyd, 2009). Bu bakımdan, çocukların öğrenme ve keşfetme isteğinin devindirilmesi gerekmektedir. İnsanı ve yaşamı anlamaya çalışan çocukların bu isteklerinin sanatçılar tarafından hazırlanmış, çocuk gerçekliğini yansıtan ve çocuğa göre olan nitelikli çocuk edebiyatı yapıtlarıyla desteklenmesi gerekmektedir. İşte, bu anlayışın yansıtıldığı çocuk kitapları, çocuğun görme ve işitme duyusunu anlam oluşturma sürecinde etkili bir biçimde kullanmasına olanak tanıyabilir. Çünkü anlam oluşturma sürecinin temelinde renk, çizgi ya da sözcüklerin yansıttığı kavramlar yer almaktadır. Bu bakımdan, nitelikli çocuk edebiyatı yapıtlarının odağında çocuğun görme ve işitme duyusunun devindirilmesi, belleğin kavram tasarımı sürecini etkili bir biçimde yapılandırmasına katkı sağlayabilir.

Çocuk edebiyatı, çocukları erken dönemden başlayarak nitelikli kitaplarla buluşturan, onları anadilinin güzellikleriyle buluşturan ilk araçlar olduğu için erken dönemde çocuğun kavram bilgisi renk ve çizgiyle oluşturulmuş görseller tarafından desteklenmelidir (Sever, 2008). Çünkü çocuk, kavramsal gelişimine katkı sağlayan bu görsellere bakarak dil ve anlam evreninin sınırlarını genişletebilir. Özellikle çocuğun 0-6 yaş döneminde dilsel simgeleri alımlayabilecek bilişsel düzeyden yoksun olması (Piaget, 2004), bu dönemde, renk ve çizgiyle oluşturulmuş kavram ve resimli kitaplara başat sorumluluk yüklemektedir (Striker, 2005). Çünkü renk ve çizgi, sözcüklerden önce kavramın bellekte tasarımını gerçekleştirir. Çocuk, görsel olarak oluşturulmuş kavramlarla girdiği etkileşim sürecinde bu tasarımlarını duyusal olarak belleğinde derece derece yapılandırmaya başlar ve sonuçta çocuk, kavramlara yönelik belleğinde biriktirdikleriyle anlam dünyasını genişletir (Miller, 2008; Gander ve Gandiner, 2010). Daha sonra anne ve babanın bilinçli çabalarıyla görsel kavramlara dilsel olarak adlar verilmesi, çocuğun anlam dünyasındaki kavramları sözel olarak ifade etmesini sağlar. Yalın bir söyleyişle, renk ve çizgiyle genişleyen çocuğun anlam evreni sözcüklerle ifade bulur. Bu nedenle, çocuğun kavram dağarcığının gelişmesi için erken dönemde çocuk edebiyatı yapıtlarının yaşamsal önemi vardır.

Bu araştırmanın problemini, kavram dağarcığının geliştirilmesinde düzeye uygun bir çocuk kitabının etkisi oluşturmaktadır. Araştırma sürecinde bu tür bir probleme yanıt aranması, kavram dağarcığının geliştirilmesinde çocuk edebiyatı yapıtlarının etkisini deneysel olarak daha somut bir biçimde ortaya çıkartabilir. Bu durum, erken dönemden başlayarak düzeye uygun bir biçimde hazırlanmış çocuk kitaplarının kavram tasarımı sürecindeki önemini eğitimcilere, uzmanlara, anne ve babalara gösterebilir.

$\mathrm{Bu}$ araştırmanın genel amacı, kavram dağarcığının geliştirilmesinde düzeye uygun bir çocuk kitabının etkisini incelemektir. Bu durum, düzeye uygun çocuk edebiyatı yapıtlarının kavram dağarcı̆ı̆ üzerindeki etkilerini ortaya çıkartabilir. Bu çerçevede, bu araştırmada aşağıdaki soruya yanıt aranmıştır:

- Kavram dağarcı̆̆ının geliştirilmesinde düzeye uygun bir çocuk kitabının etkisi var mıdır?

\section{Yöntem}

Bu bölümde, araştırmanın deseni, katıımcı ve uygulayıcı, veri toplama araçları ile verilerin çözümlenmesi ile ilgili ayrıntılı bilgiler sunulmuştur.

\section{Araştırmanın Deseni}

Bu araştırma, kavram dağarcığının geliştirilmesinde düzeye uygun bir çocuk kitabının etkisinin incelendiği tek denekli araştırmadır. Tek denekli araştırmalar, standart koşullar altında yinelenen ölçümler yapılarak davranış değiştirme ya da öğretim uygulamalarının etkililiğini ortaya koyan araştırmalardır (Tekin-iftar, 2018). Bu yönüyle, bu araştırmada tek denekli araştırma desenlerinden birisi olan $A B A B$ modeli uygulanmıştır. $A B A B$ modeli, başlama düzeyinin ölçülmesi ve deneysel işlemin yapıldığı $A B$ modelindeki işlemlerin bir kez daha yinelenmesiyle gerçekleştirilir. $A B A B$ modelinde bağımsız değişkenin etkisi yinelenerek ölçülür. Daha açık bir anlatımla, herhangi bir tek denekli araştırmanın ilk B evresinde görülen değişiklik ikinci B evresinde de görülürse uygulamanın etkiliği yineleme özelliğine göre ortaya konur ve okuyucuların uygulamanın etkiliğine yönelik inancı güçlenir 
(Tekin, 2000). Bu yönüyle, bu araştırmada iki yaşında olan bir bebeğin nitelikli çocuk edebiyatı yapıtlarıyla kavram tasarımı sürecini nasıl yapılandırdığı $A B A B$ modeliyle gösterilmeye çalışılmıştır. Daha önce yapılan bir araştırmada, 0-24 aylık süreçte bebeğin öğretici ve yazınsal kitaplarla kurduğu etkileşim sonucunda gözlemle kayıt altına alınabilen kavram sayısı 1053'tür (Yazar, 2019). Yani, araştırma sürecinde bebeğin 0-24 aylık süreçte elde ettiği kavram sayısı başlama düzeyi olarak belirlenmiştir. Başlama düzeyi belirlendikten sonra nitelikli çocuk edebiyatı yapıtlarının bebeğin kavram tasarımı sürecini nasıl yapılandırdığını göstermek için uygulayıcı ele aldığı kitabı bebekle karşı karşı getirerek bir hafta sürecek birinci uygulama sürecinde 8 alt uygulama evresiyle deneysel işlemi gerçekleştirmiştir. Bundan sonra ise uygulayıcı ikinci uygulama sürecinde bir hafta sürecek 2 alt uygulama evresiyle bebeğe bir önceki uygulama evresinde verilen kitabı yeniden okumuş ve bebeğin kavram tasarımı sürecinde elde ettiği kavramları yeniden kayıt altına almıştır.

\section{Katılımcı ve Uygulayıcı}

Bu araştırmanın katııımcısı, araştırmacının iki yaşında (24. ayda) olan bebeğidir. Araştırmacının kendi çocuğunu araştırma sürecine katmasının nedeni, kavram dağarcı̆ı̆ın geliştirilmesinde düzeye uygun bir çocuk kitabının etkisini gözlemleyebileceği, yaklaşık iki hafta sürecek ve belli aralıklarla uygulama yapabileceği iki yaşında olan bir katılımcı bulmasının zor olmasıdır. Bu yönüyle araştırmacının, araştırma sürecinde kendi çocuğuyla sürekli olarak etkileşim ve iletişim içinde olması, onun bu süreçte nitelikli veriler elde etmesine katkı sağlayacağı düşünülmüştür. Bu araştırmanın uygulayıcıyı ise, bebeğin babasıdır. Uygulayıcı, Türkçe eğitimi alanında doktora derecesini almış olup "Çocuk Edebiyatı" alanında doktora tezi yazmıştır. Uygulayıcının çocuğa görelik, çocuk edebiyatı yapıtları, anlama ve anlatma becerileri, üstbilişsel strateji ve yaratıcı drama konularında çalışmaları bulunmaktadır.

\section{Veri Toplama Araçları}

Bu bölümde, veri toplama sürecinde düzeye uygun bir çocuk kitabının seçimi, çocuk ile kitap ilişkisinin gerçekleşeceği ortamın düzenlenmesi ve $A B A B$ deseninin uygulama sürecine yönelik bilgi verilmiştir.

\section{Düzeye Uygun Çocuk Kitaplarının Seçimi}

Bu araştırmada, bebeğin kavram dağarcığını nasıl geliştirdiğini göstermek için yazınsal nitelikli bir kitap kullanılmıştır. Çünkü yazınsal nitelikli kitaplar, çocuğun düş kurma ve düşünme sorumluluğu alarak kitabı duyumsamaya çalıştığı sözcükle ya da sözcüksüz oluşturulmuş resimli kitaplardır. Yazınsal nitelikli kitapların başat amacı ise, çocuklara insana özgü duyarlıklar kazandırmak, onların duyma, sezme ve düşünme güçlerini geliştirmektir (Sever, 2008). Bütün bu yönleriyle, bu araştırmada 24. ayda katılımcının etkileşim sağlayacağı yazınsal nitelikli bir kitabın seçiminde çocuk gerçekliği, çocuğa görelik ilkeleri ve uzman görüşü etkili olmuştur. Bu yönüyle, araştırmacı ilk olarak katılımcının etkileşim kurmak isteyebileceği yazınsal kitapları bebeğin gelişimsel olarak yansıttığı gerçekliğini önceleyerek belirlemeye çalışmıştır. Daha açık bir anlatımla, çocuğun içinde bulunduğu 24. aydaki gelişimsel özellikleri belirlendikten sonra (Yavuzer, 2012; Yörükoğlu, 2010), bebeğin düzeyine uygun 3 kitap seçilmiştir. Bu kitaplar, "Benim Minik Kırmızı Balığım" (Avcı, 2014), "Kırmızı Fil’i Gördünüz Mü?” (Avcı, 2010) ve "Uyurgezer Fil" (Ak, 2011)'dir. Bu araştırmada, bebeğin 24. aydaki gelişimsel özelliklerinin yansıdığı kitaplar araştırmacı tarafından belirlendikten sonra kitapların çocuğa göre olup olmadığını belirleyebilmek için ise kitaplar Sever (1995) tarafından oluşturulan çocuğa görelik ilkeleri bakımından değerlendirilmiştir. Bu değerlendirmeler, araştırmacıyla birlikte çocuk edebiyatı alanında uzman iki kişiyle birlikte gerçekleştirilmiştir. Bu araştırmada, alan uzmanları yazınsal nitelikli kitapları tasarım, içerik ve eğitsel olarak değerlendirmiştir. Alan uzmanları iki haftalık süreç içinde 3 kitabı çocuğa görelik ilkeleri bağlamında değerlendirdikten sonra her bir uzmanın yapmış olduğu değerlendirmeler araştırmacı tarafından elektronik ortama aktarılarak SPSS üzerinde çözümlenmiştir. Bu yönüyle, alan uzmanlarının yapmış oldukları değerlendirmeler arasındaki güvenirlik, sınıf içi korelasyon katsayısı kullanılarak hesaplanmıştır. Kitapların çocuğa görelik ilkeleri bakımından hesaplanan sınıf içi korelasyon katsayıları "Benim Minik Kırmızı Balığım” başlıklı kitabın tasarım özellikleri için 85, içerik 
özellikleri için 89 ve eğitsel özellikleri için 95'tir. "Kırmızı Fil'i Gördünüz Mü?” başlıklı kitabın tasarım özellikleri için 82, içerik özellikleri için 85 ve eğitsel özellikleri için 90'dır. "Uyurgezer Fil" başlıklı kitabın tasarım özellikleri için 84 , içerik özellikleri için 87 ve eğitsel özellikleri için 91 'dir. Belirlenen sınıf içi korelasyon katsayılarına göre değerlendiriciler arası hesaplamaların güvenilir olduğu görüldüğünden kitapların çocuğa göre olduğu ortaya çıkartılmıştır. Bütün bu yönleriyle araştırmacı, her üç kitabı uygulama öncesinde bebekle karşı karşıya getirmiş ve birkaç denemeden sonra bebeğin ilgisini daha çok çeken “Kırmızı Fil'i Gördünüz Mü?” kitabı uygulama sürecinde kullanılmıştır. Bununla birlikte, uygulayıcının bebeğe bu kitaplardan hangisini okuyalım sorusuna bebeğin “Kırmızı Fil'i Gördünüz mü?” başlıklı kitabı işaret ettiği görülmüştür. Bütün bu yönleriyle, uygulayıcının böyle bir yaklaşımı belirlemesinin nedeni, uygulayıcı ve uzmanların katkısıyla her üç kitap içerik, tasarım ve eğitsel olarak çocuğa görelik ilkeleri bakımından değerlendirilmiş olsa da bebeğin ilgisini daha çok çeken kitabın yeğlenmiş olmasıdır. Bu durum, yinelenerek deneysel işlemlerin yapıldığı uygulama sürecinde bebeğin hem ilgisinin çok fazla dağılmasını önlemiş hem de kavram dağarcı̆ının geliştirilmesinde bir çocuk kitabıyla çalışıımasına olanak tanımıştır.

\section{Çocuk ile Kitap ilişkisine Yönelik Ortamın Düzenlemesi}

$\mathrm{Bu}$ araştırmanın uygulama çalışmaları, bebeğin özgür ve rahat bir biçimde oyun oynamasına olanak tanıyan ev ortamında gerçekleştirilmiştir. 24. ay içerisinde bebeğin kitaplarla etkileşim kurduğu uygulama zamanları içinde dikkati dağıtan oyuncak, televizyon ve telefon gibi uyaranlar ortamdan uzaklaştırılmıştır. Daha ayrıntılı bir anlatımla, araştırmacı uygulama sürecini olumsuz etkileyebilecek uyaranları göz önüne alarak bebeğin kitapla etkileşim kurduğu ortamı düzenlemiştir. Örnek olarak, araştırmacı bebek yere oturduğu zaman kitabı çocuğun önüne koyarak çocuğun kitapla etkileşimi sağlamış ya da çocuğun kitabı tuttuğu ve kitabın sayfalarını çevirdiği zamanlarda çocuğun kitapla etkileşimini sürdürmesine olanak tanımıştır.

\section{Uygulama Süreci}

$\mathrm{Bu}$ araştırmanın uygulama sürecinde belirlenen kitaptaki görseller bebeğe gösterilirken uygulayıcı görselleri ses ve devinimle anlatmaya çalışmıştır. Bu süreçte uygulayıc bebeğin her bir kitabın sayfasında yer alan olayları sezinleyebilmesi için gizem ve merak uyandırıcı söyleyiş özellikleri kullanmıştır. Örnek olarak, "Kırmızı Fil'i Gördünüz Mü?” (Avcı, 2010) başlıklı kitapta uygulayıcı ilgili görselde yer alan "Kırmızı Fil nereye gitmiş?" sorusunda yükselen ve alçalan bir ses tonuyla vurguyu son sözcüklere yönelterek kitabı okumuştur. Buradaki başat amaç, bebeğin kitapla kurduğu etkileşim süresini arttırarak ilgili sorulara yanıt almak ve bebeğin öğrendiği kavramlarla kitabı anlatmasına olanak tanımaktır. Uygulama sürecinde, bebeğin kitaplarla kurduğu etkileşim sonrasında uygulayıcı bebeğin söylediği her bir kavramı tarih vererek kayıt altına almıştır. Bununla birlikte, uygulama sürecinde bebeğin adı (Adı) biçiminde kodlanmış ve ilgili verilere yazılmıştır.

\section{Başlama Düzeyleri ve Uygulama Evreleri}

Bu araştırmada başlama düzeyi bebeğin içinde bulunduğu 24. aydır. Uygulayıcı bu ayın ilk haftasında deneysel işlemi gerçekleştirerek bebeğin öğrendiği kavramları kayıt altına almıştır. Elde edilen kavramlar doğrultusunda uygulayıcı araştırma sürecinde kullandığı kitabın kavram dağarcığına yönelik etkisini yeniden gözlemleyebilmek için ikinci başlama düzeyini belirlemiş ve 24 . ayın ikinci haftasında ikinci uygulamayı gerçekleştirmiştir.

\section{Haftadaki Uygulama Evreleri}

Bu süreçte her gün farklı saatlerde tamamlanan 5-15 dakikalık zaman dilimlerinde bebeğe verilen kitap 8 alt uygulama evresinde gösterilmiştir. Bu uygulama evresinde bebek daha önceden bu kitapla karşılaşmadığı için bebeğin ilk önce kitaba bakmasına ve görsellerini incelemesine olanak tanınmıştır. Daha sonra bebeğin kitapta yer alan kurguyu görsellerde yer alan kavramlar aracılığıyla sezinlemesine yönelik eylemler gerçekleştirilmiştir. Örnek olarak, bu süreçte bebeğin kitapla etkileşim kurması için uygulayıcı “(Adı), bu fil hangi renk sence?” ve "Aaa, Kırmızı Fil nereye gitmiş?” gibi bebeğin kitaba yönelik ilgisinin artması için merak ve gizem uyandırıcı söz ve eylemler kullanılmıştır. Böylelikle 
bebeğin kitabı bir hafta boyunca görsel olarak okumasına olanak tanınarak elde edilen kavramlar her bir uygulama evresinde kayıt altına alınmıştır. Bununla birlikte, bebeğe kitapta yer alan kavramlar gösterilirken bebeğin uygulayıcıyı taklit edebileceği bilindiğinden (Yavuzer, 2012), bebeğin kitapta yer alan kavramları öğrenip öğrenmediğini belirleyebilmek için her bir uygulama evresi içinde bebeğe "(Adı), bu hayvanın adı ne?", "Sence burada ne olmuş?", "Kırmızı Fil neden üzgün?" gibi sorular sorulmuştur. Bu uygulama evresi sonucunda bebeğin edindiği kavram sayısı not edilerek kayıt altına alındıktan sonra ikinci uygulama sürecine geçilmiştir.

\section{Haftadaki Uygulama Evreleri}

Bu süreçte aynı kitap her gün farklı saatlerde tamamlanan 5-15 dakikalık zaman dilimlerinde 2 alt uygulama evresini kapsayacak biçimde bebeğe gösterilmiştir. Daha açık bir anlatımla, ilk haftada araştırmacı tarafından gerçekleştirilen bütün eylemler bu uygulama evrelerinde de yinelenerek yapılmıştır. İkinci haftada bebeğin aynı türden kitapla sürekli olarak etkileşim içinde olması, kitabı tanıması ve görsellere çok fazla bakmak istememesi gibi gerekçelerden dolayı bu uygulama süreci 2 alt uygulama evresiyle sınırlı tutulmuştur. Bu uygulama evrelerinde ise, uygulayıcı bebeğin ilk haftada kavram tasarımı sürecini gerçekleştiremediği görsellerle ilgilenmesini sağlamıştır. Sonuç olarak, bu uygulama evrelerinde bebeğin edindiği kavramlar not edilerek kayıt altına alınmıştır.

\section{Verilerin Analizi}

Bu araştırmada, 24. ayda olan bir bebeğin kavram dağarcığının geliştirilmesinde bir çocuk kitabının etkisine yönelik elde edilen veriler betimsel olarak çözümlenmiştir. Betimsel çözümleme, birçok kaynaktan elde edilen kaynakların betimlenmesinde, düzenlenmesinde ve yorumlanmasında araştırmacıya olanak tanır. Bununla birlikte betimsel çözümleme, çeşitli veri toplama teknikleri ile elde edilmiş verilerin daha önceden belirlenmiş temalara göre özetlenmesi ve yorumlanmasını içeren bir nitel veri analiz türüdür. Bu analiz türünde araştırmacı görüştüğü ya da gözlemiş olduğu bireylerin görüşlerini çarpıcı bir biçimde yansıtabilmek amacıyla doğrudan alıntılara sık sık yer verebilmektedir. Bu analiz türünde temel amaç elde edilmiş olan bulguların okuyucuya özetlenmiş ve yorumlanmış bir biçimde sunulmasıdır (Yıldırım ve Şimşek, 2005). Bu bakımdan uygulayıcı, bebek ile arasında geçen kitaba yönelik konuşmaların tamamını alıntı biçimde vererek bebeğin kavram dağarcığını nasıl geliştirdiğini ve edindiği kavramları betimsel olarak ortaya koymuştur.

\section{Bulgular}

Bu bölümde, bebeğin "Kırmızı Fil’i Gördünüz Mü?" başlıklı kitaptan edindiği kavramlarla ilgili bulgulara yer verilmiştir. Birinci ve ikinci uygulama evrelerinde bebeğin edindiği kavramlar ilgili görsellerle verilerek kavram dağarcığını nasıl yapılandırdığı gözler önüne serilmiştir.

\section{Birinci Haftadaki Uygulama Evrelerine Yönelik “Kırmızı Fil’i Gördünüz Mü?” Başlıklı Kitaptan Elde Edilen Bulgular}

Bu bölümde, sekiz alt uygulama evresiyle bebeğin kitabın tamamına yönelik elde ettiği kavramlar ortaya konan alıntılarla ayrıntılı bir biçimde gösterilmiştir.

\section{Birinci Alt Uygulama Evresi}

Bu alt uygulama evresinde, bebek ilk olarak kitabın kapağıyla karşı karşıya getirilmiş ve bebeğe kitabın kapağında yer alan görseller merak ve gizem uyandırıcı bir biçimde hem adlarıyla yinelenmiş hem de işaret ve devinimle gösterilmiştir. Bu yönüyle, uygulayıcı bebeğe ilk olarak kitabın kapağına yönelik aşağıdaki konuşmayı gerçekleştirmiştir:

\footnotetext{
Uygulayıcı: - Aaa, bak Kırmızı Fil. Çocuk, Kırmızı Fil'in hortumuna sarılmış. Görüyor musun?

Bebek: $\quad-$... (Dinleme, bakma ve inceleme).

Uygulayıcı: - (Adı), baksana (Şaşkınlık içinde). Burada kırmızı bir fil var! Sen hiç Kırmızı Fil gördün mü? (Yineleyerek).
} 

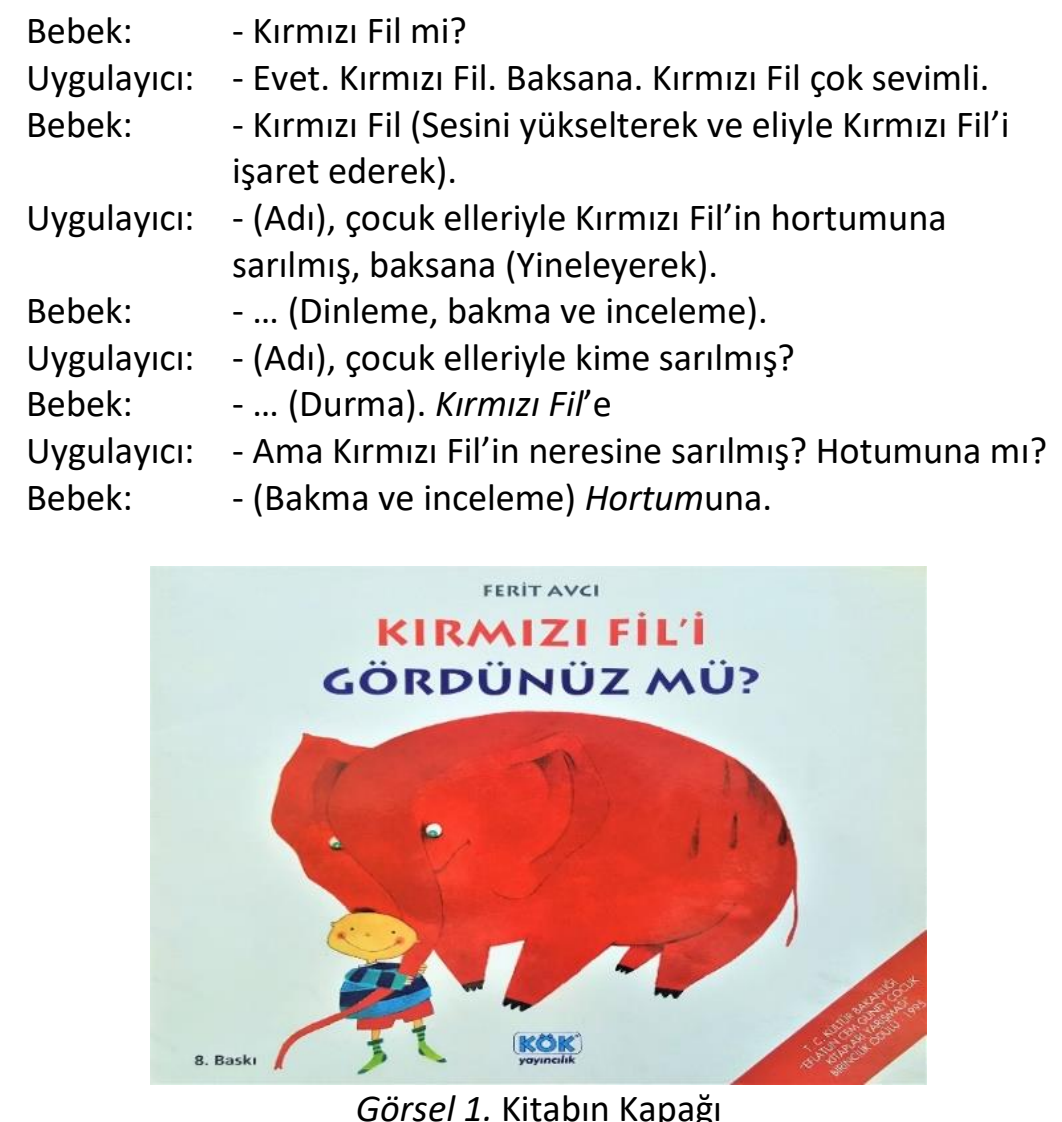

Bebek ile kitabın kapağı arasındaki ilişkiye bakıldığında, uygulayıcı tarafından kitabın kapağına yönelik olarak söylenen açıklamalar bebeğin kapakta yer alan kavramları sezinlemesine olanak tanımıştır. Farklı bir söyleyişle, bebek "fil" kavramını uygulayıcı tarafından daha önceden verilen kitaplardan bilmesine karşın "Kırmızı Fil" ve "hortum" kavramıyla ilk kez karşı karşıya gelmiştir. Bu durum, bebeğin kavram tasarımı sürecinde daha kitabın kapağında bilmediği iki kavramı belleğinde yapılandırmasına olanak tanımıştır. Bununla birlikte, bebeğin sezinlediği "Kırmızı Fil" kavramı, onun kitabın içeriğinde yer alan kurguya yönelik anlamsal ilişkisini de belirlemiştir. Çünkü, bebek "Kırmızı Fil” $i$ kapaktaki resminden dolayı tanımış ve ilgili resmi hem görsel hem de adıyla eşleştirmiştir. Bu durum, uygulayıcının bebeğe yönelik ikinci alt uygulama evresinde sunulan "Kırmızı Fil nerede?" sorusuyla kendini daha çok belirgin kılmıştır.

\section{ikinci Alt Uygulama Evresi}

İkinci alt uygulama evresinde, bebek ile kitabın ilk sayfası arasındaki ilişkiye bakıldığında uygulayıcı sayfada yer alan görsel kavramları ve kurguyu sezinletecek biçimde aşağıdaki konuşmayı gerçekleştirmiştir:

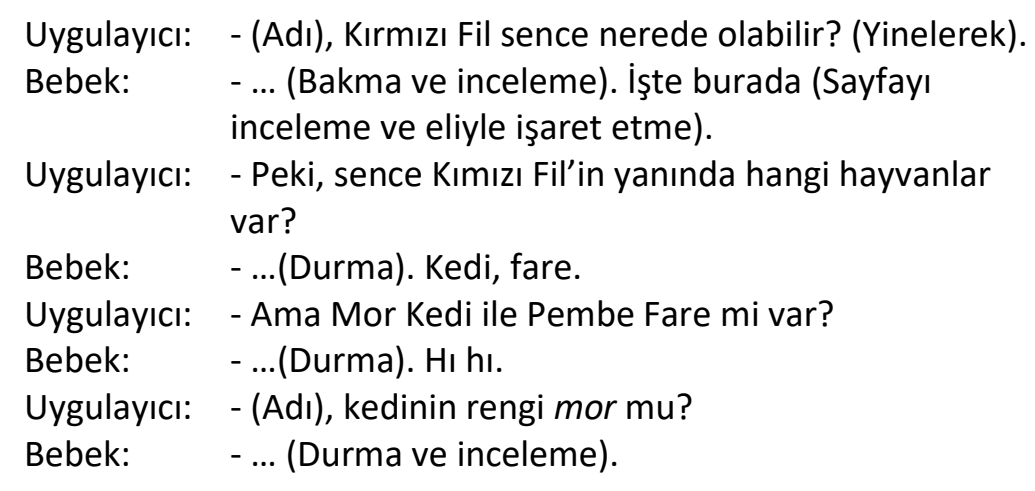



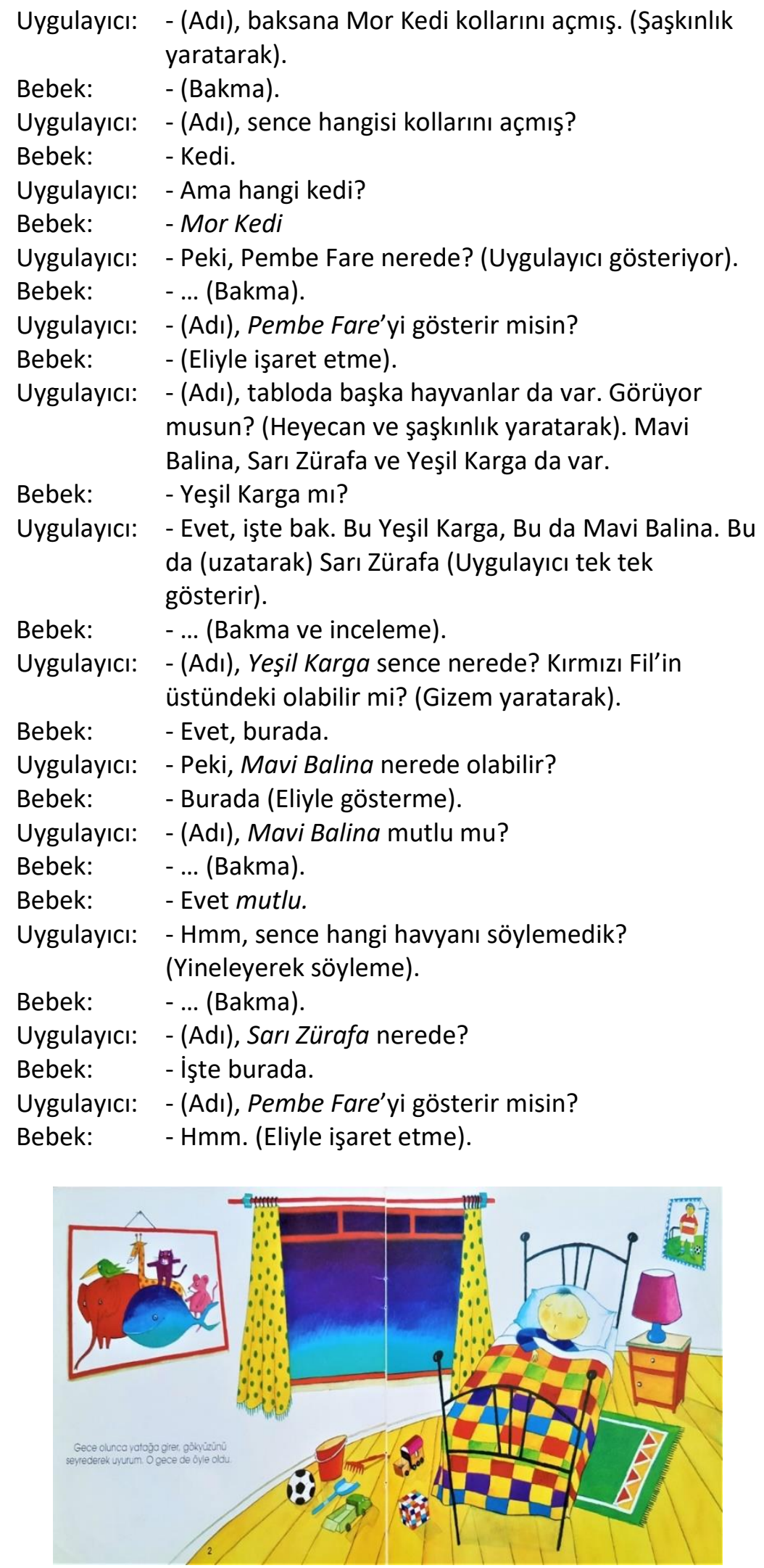

Görsel 2. Kitabın Illk Sayfası

Bebek ile uygulayıcı arasında kitabın ilk sayfasına bağlı olarak gerçekleştirilen konuşmalar incelendiğinde, uygulayıcı bebeğin sayfada yer alan tabloya yoğunlaşmasını sağlayarak onun burada yer alan kavramları görsel olarak sezinlemesine olanak tanımıştır. Çünkü kitabın baş karakteri olan 
çocuğun, Kırmızı Fil ile ilgili yaşadığı serüvende tabloda yer alan hayvanlar başat rol oynamaktadır. Bu bakımdan, uygulayıcı şaşkınlık ve gizem yaratıcı soru tümceleri kullanarak tabloda yer alan görsel kavramları bebeğin algılamasını kolaylaştırıcı biçimde anlatmaya çalışmıştır. Özellikle tamlama biçiminde yer alan söz öbeklerinin sezinletilmesinde uygulayıcı ilgili söz öbeğini yinelerek ve vurgularak bebeğin ilgili görsele yönelmesini sağlamıştır. Bütün bu yönleriyle, bebek "Mavi Balina, Pembe Fare, Sarı Zürafa ve Yeşil Karga"yı gösteren söz öbeklerini kavramsallaştırmış ve uygulayıcı görselde yer alan hayvanları sorduğunda tamlama biçiminde ilgili hayvanların renk ve adlarını birlikte söylemiştir.

\section{Üçüncü Alt Uygulama Evresi}

Üçüncü alt uygulama evresinde, kitabın ilk sayfasındaki tablo dışında yer alan görsellere yoğunlaşılarak bebeğin hem diğer kavramları hem de kurguyu sezinleyebilmesi için aşağıda yer alan konuşma gerçekleştirmiştir:

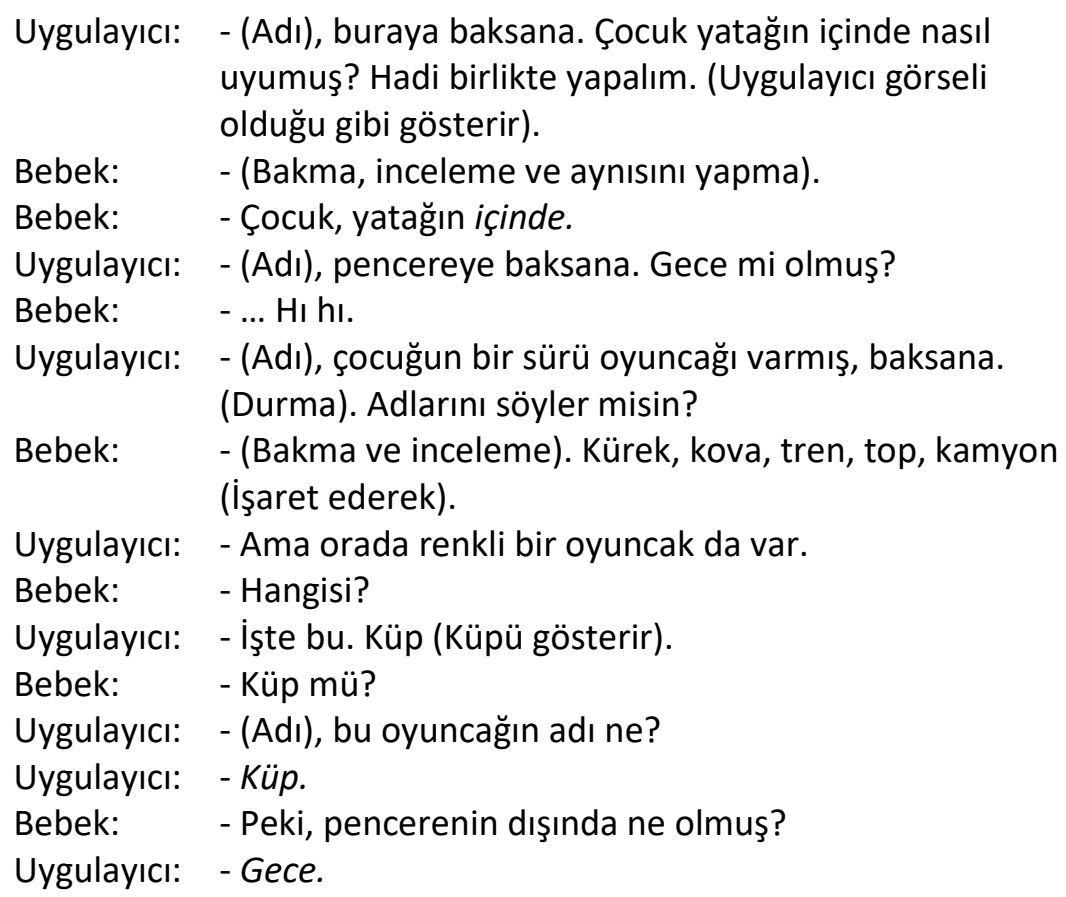

Bebek ile uygulayıcı arasında kitabın ilk sayfasına bağlı olarak tablo dışında gerçekleştirilen konuşmalar incelendiğinde, bebeğin ilk sayfada yer alan "çocuk, yatak, pencere, tren, kamyon, top, kürek" kavramlarını daha önceden farklı kitaplardan uygulayıcıyla birlikte görsel okuma yaparak bildiği bilinmektedir (Yazar, 2019). Bu alt evrede ise, bebek daha önceden bilmediği "Küp, içinde ve gece" kavramlarını sayfada yer alan görsellerle ilişki kurarak sezinlemiştir. Bununla birlikte, uygulayıcının baş karakterin ilk sayfada ne yaptığına yönelik soruları, bebeğin kitabın kurgusuna ortak olabilmek için sayfada yer alan görselleri adlandırmasına olanak tanımıştır. Bu durum, sayfadaki görselleri tek tek değerlendiren bebeğin edindiği kavramsal birikimiyle anlama ve anlatma becerilerine sorumluluk yüklediğini de göstermektedir. Çünkü, bebek sayfada adlarını bildiği kavramları hem ses hem de devinimle anlatırken adlarını bilmediği kavramları salt işaret ederek anlatmıştır. Bu durum, görsel okuma sürecinde kavram tasarımının önemini ortaya koymaktadır.

\section{Dördüncü Alt Uygulama Evresi}

Dördüncü alt uygulama evresinde, kitabın ikinci sayfasındaki görsellere yoğunlaşılarak bebeğin hem ikinci sayfanın ilk sayfayla olan karşıtlığını sezinleyebilmesi hem de bu karşıtlığın sonucunda ikinci sayfadaki kavramları duyumsayabilmesi için aşağıda yer alan konuşma gerçekleştirmiştir:

Uygulayıcı: - (Adı), pencereye baksana hava aydınlanmış; gündüz olmuş ve yağmur yağıyor. 
Bebek: - - (Bakma ve inceleme). Gündüz mü? Yağmur (Uzatma).

Uygulayıcı: - Evet, bak hava aydınlanmış yani gündüz olmuş.

Bebek: - Gündüz olmuş.

Uygulayıcı: - (Adı) bak, çocuk uykusundan uyanmış ve çocuk yatağın üstünde çok şaşırmış görünüyor. Hadi sen de çocuğun yaptığı gibi yapsana (Uygulayıcı, karakterin yaptığı gibi yapar ve bebeğin de aynısını yapmasını sağlar).

Bebek: - (Karakteri inceleme ve aynısını yapma). Çocuk uyanmış, çok şaşırmış.

Uygulayıcı: - (Adı), sence çocuk neden şaşırmış olabilir? O da ne! Tabloda Kırmızı Fil yok! (Adı), Kırmızı Fil gitmiş, baksana (Alçalan ses tonuyla şaşkınlık ve gizem yaratarak).

Bebek: $\quad$ - (Tabloya bakma ve inceleme). Kırmızı Fil yok, gitmiş (Aynı şaşkınlık içinde).

Uygulayıcı: - (Adı), nereye gitmiş Kırmızı Fil, sen gördün mü?

Bebek: - Hayır. (Önceki sayfayı çevirme). Burada Kırmızı Fil var. (Sonraki sayfayı çevirme). Burada yok. Gitmiş. (Şaşkınlık devam eder).

Uygulayıcı: - Gördün mü, bak Mavi Balina çok üzülmüş Kırmızı Fil gitti diye.

Bebek: - (Mavi Balina'yı inceleme, önceki sayfayı çevirme).

Uygulayıcı: - (Adı), tablo eğik, gördün mü?

Bebek: - Hı hı. (Önceli sayfaya bakma).

Bebek: - Eğik (Sözcüğü uzatma).

Uygulayıcı: - Ama ilk sayfada tablo düz!

Bebek: - Düz (Önceki sayfaya bakma).

Uygulayıcı: - Peki, şimdi ne olacak? (Adı), Kırmızı Fil nereye gitmiş olabilir?

Bebek: $\quad-\ldots$ (Diğer sayfayı çevirme).

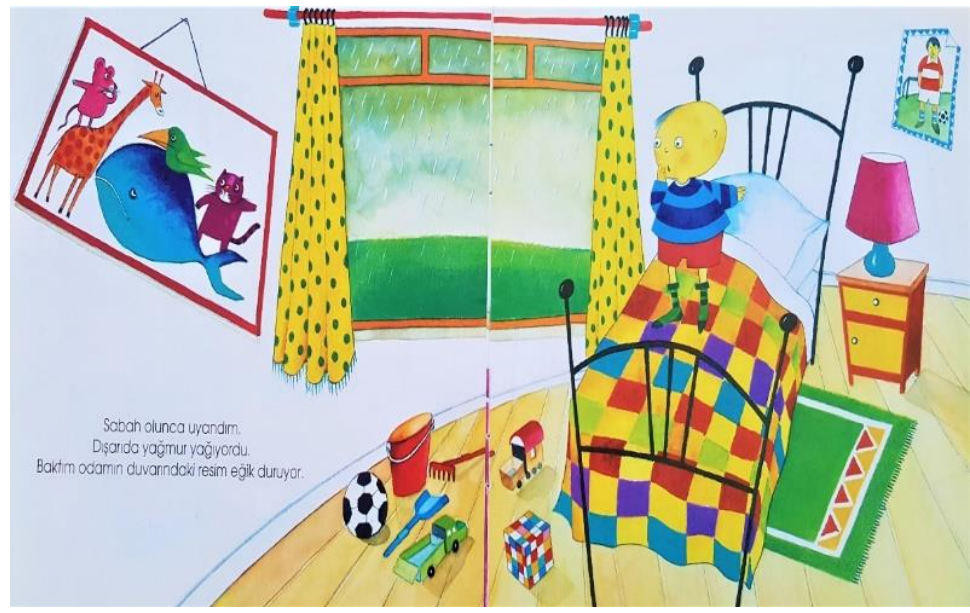

Görsel 3. Kitabın İkinci Sayfası

Bebek ile uygulayıcı arasında kitabın ikinci sayfasına yönelik olarak gerçekleştirilen konuşmalar incelendiğinde, Kırmızı Fil'in tablodan aniden kaybolması ve çocuğun elini ağzına götürmesiyle belirgin kılınan şaşkınlık, heyecan ve gizem yüklü kurgusal ortam uygulayıcı tarafından bebeğe sezinletilmiştir. Bu kurgusal ortam içinde Kırmızı Fil'in aniden ortadan koybolması sonucunda Mavi Balina'nın üzülmesi, 
çocuğun yatağın üstünde ayağı kalkması ve tablonun eğilmiş olması, bebeğin ilk sayfaya bağlı olarak kavramsal karşıtıkla görselleri duyumsamasına olanak tanımıştır. Çünkü bebek "Kırmızı Fil var/ Kırmızı Fil yok, Mavi Balina mutlu/Mavi Balina üzgün, çocuk uyanmış/çocuk uyanık, yatağın içinde/yatağın üstünde, gece/gündüz, eğik/düz ve şaşırma/şaşırmama"ya yönelik karşıt kavramları sezinleyerek hem kurguyu çözümlemeye hem de kavramsal tasarımını karşıt sözcüklerle yapılandırmaya başlamıştır.

\section{Beşinci Alt Uygulama Evresi}

Beşinci alt uygulama evresinde, kitabın üçüncü sayfasına yoğunlaşılarak Kırmızı Fil'in kaybolmasıyla çocuk karakterin ne/neler yaptığının bebeğe sezinletilebilmesi için aşağıda yer alan konuşma gerçekleştirmiştir:

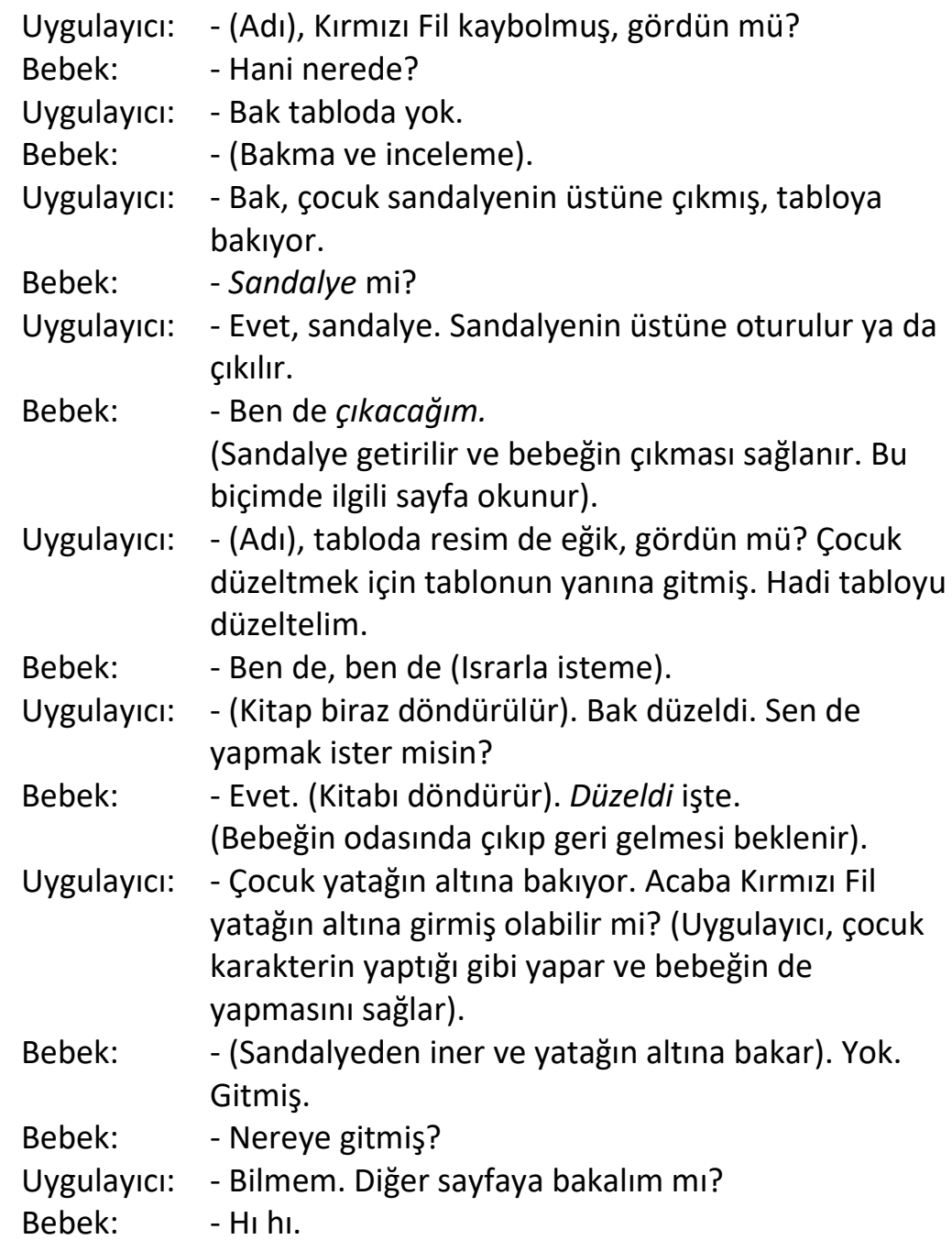




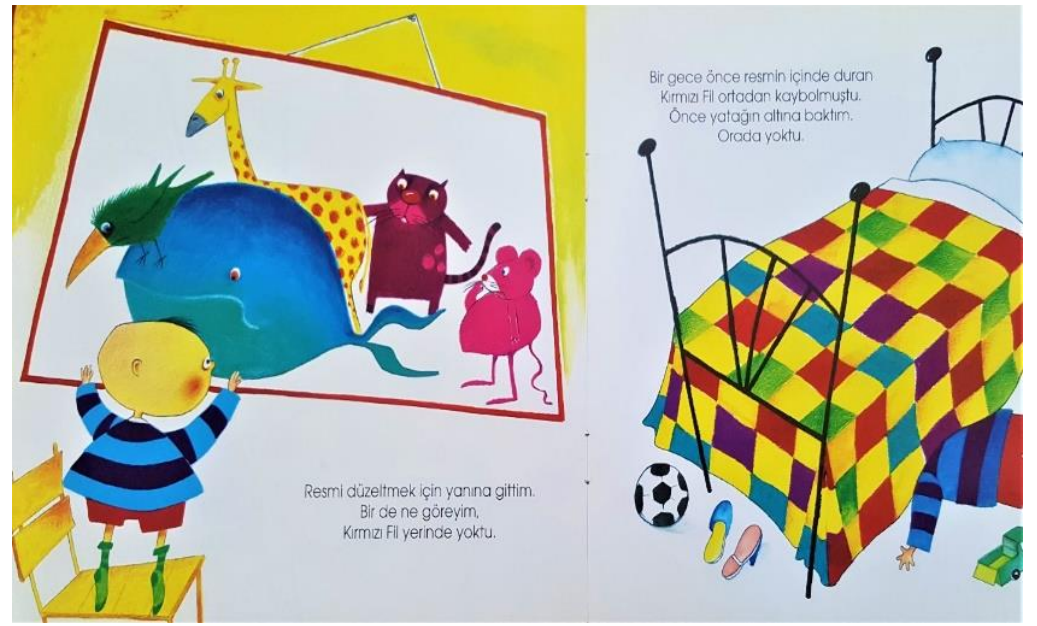

Görsel 4. Kitabın Üçüncü Sayfası

Bebek ile uygulayıcı arasında kitabın üçüncü sayfasına yönelik olarak gerçekleştirilen konuşmalar incelendiğinde, Kırmızı Fil'in kaybolmasıyla çocuk karakterin merak ve keşfetme isteğinin bir sonucu olarak tabloyu incelemesi ve yatağının altına bakması, bebeğin de aynı davranışları göstermesini sağlamıştır. Bebek, bu davranışları gerçekleştirirken görsellerde yer alan "Sandalye, (üstüne) çıkmak, düzelmek" kavramlarını kullanarak hem sayfalarda yer alan olayı duyumsamaya başlamış hem de bilme ve tanıma isteğiyle görsellere yoğunlaşmıştır. Bu durum, bebeğin sezinlediği kavramlarla görsellerdeki olay ya da durumu algılayarak, ilişki kurarak ya da karşılaştırarak anlamaya ve adlandırmaya çalışmasının bir sonucudur.

\section{Altıncı Alt Uygulama Evresi}

Altıncı alt uygulama evresinde, kitabın dördüncü sayfasına yoğunlaşılarak çocuk karakterin elbise dolabını araması ile Mavi Balina'ya yönelik sorularıyla oluşan durumu bebeğin sezinleyebilmesi için aşağıda yer alan konuşma gerçekleştirmiştir:

Uygulayıcı: - (Adı), Kırmızı Fil elbise dolabına gitmiş olabilir mi? Baksana resimdeki çocuğa dolabı arıyor. Çocuğun elbiseleri her yana dağılmış.

Bebek: - (Bakma ve inceleme). Bak, çorap ve mendil. (Çorap ve mendili işaret eder).

Uygulayıcı: - Peki kravat nerede?

Bebek: - Kravat mı?

Uygulayıcı: - İşte burada (Kravat işaret edilir).

Bebek: - (Bakma ve inceleme).

Uygulayıcı: - Uygulayıcı kravat getirir ve boynuna takar). Gördün mü, kravat boyuna takılır.

Bebek: - Ben de takacağım.

Uygulayıcı: - (Boynuna takmasına yardım edilir). Peki, çocuğun elinde ne var? Gördün mü?

Bebek: - Hangisi?

Uygulayıcı: - Çocuğun eline baksana. Orada atkı mı var?

Bebek: - Atkı mı?

Uygulayıcı: - Evet, atkı. (Uygulayıcı atkı getirip boynuna dolar). Boynuna dolamak ister misin?

Bebek: - Ben de, ben de dolayacağım.

Uygulayıcı: - (Atkı, bebeğin boynuna dolanır). (Bebek, biraz sona atkı ve kravatı çıkarır). $O$ da ne? (Adı), dolabın 

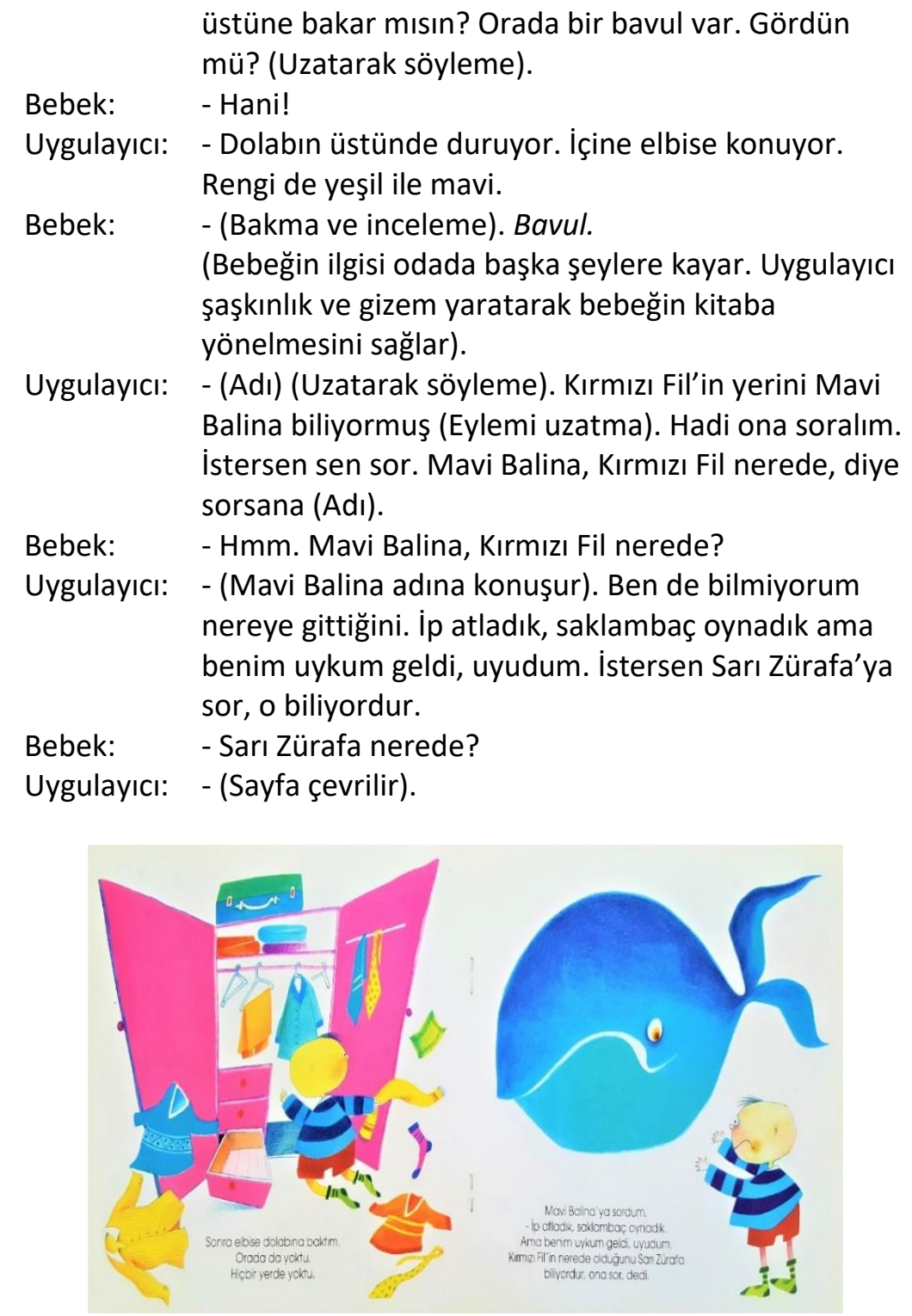

Görsel 5. Kitabın Dördüncü Sayfası

Bebek ile uygulayıcı arasında kitabın dördüncü sayfasına yönelik olarak gerçekleştirilen konuşmalar incelendiğinde, çocuk karakterin Kırmızı Fil'i bulmak için dolabı ararken elbiselerini dağıtması, bebeğin de bu elbiseleri tanımasına ve adlarını sezinlemesine olanak tanımıştır. Özellikle, bebeğin kavram dağarcığında olmayan "Kravat, takmak, atkı, dolamak ve bavul" sözcüklerini görsellerden yola çıkarak uygulamalı olarak sezinlemesi ve bu sözcüklerin işlevlerini öğrenmesi, bebeğin ilgili görselleri daha çok incelemesine katkı sağlamıştır. Bununla birlikte, Kırmızı Fil'in hala bulunamaması, bebeğin ilgisinin uygulayıcı tarafından Mavi Balina'ya yöneltilmesini gerekli kılmıştır. Uygulayıcı tarafından, bebeğin Mavi Balina'ya yönelik soru sordurulması ve alınan yanıtlar doğrultusunda Sarı Zürafa'ya yönlendirilmesi, bebeğin her iki kavramı sezinlediğini ortaya koymaktadır.

\section{Yedinci Alt Uygulama Evresi}

Yedinci alt uygulama evresinde, kitabın beşinci sayfasına yoğunlaşılarak çocuk karakterin Sarı Zürafa'ya, Mor Kedi'ye ve Pembe Fare'ye yönelik sorularını bebeğin sezinleyebilmesi için aşağıda yer alan konuşma gerçekleştirmiştir:

Uygulayıcı: - (Adı), belki Sarı Zürafa, Kırmızı Fil'in nereye gittiğini biliyordur. Hadi ona soru soralım. (Adı), Sarı 


\begin{tabular}{|c|c|}
\hline & $\begin{array}{l}\text { Zürafa'ya şöyle söyler misin? Sarı Zürafa, Kırmızı } \\
\text { Fil'in yerini biliyor musun? }\end{array}$ \\
\hline Bebek: & - Sarı Zürafa, Kırmızı Fil'in yerini biliyor musun? \\
\hline Uygulayıcı: & $\begin{array}{l}\text { - (Uygulayıcı yanıt verir). Hayır bilmiyorum. Gece } \\
\text { saklambaç oynadık ama nerede olduğunu } \\
\text { bilmiyorum. }\end{array}$ \\
\hline Bebek: & - Hmm. \\
\hline Uygul & $\begin{array}{l}\text { - O zaman biz de Mor Kedi'ye soralım. Mor Kedi, } \\
\text { Kırmızı Fil nerede? (Sorması sağlanır). }\end{array}$ \\
\hline Bebek: & - Mor Kedi, Kırmızı Fil nerede? \\
\hline Uygulayıcı: & $\begin{array}{l}\text { - (Uygulayıcı yanıt verir). Bilmiyorum ki. İstersen } \\
\text { Pembe Fare'ye sor. }\end{array}$ \\
\hline Bebek & - (Durma). \\
\hline Uygulayıcı: & $\begin{array}{l}\text { - Hadi Pembe Fare'ye soralım. Pembe Fare, Kırmızı } \\
\text { Fil nerede? }\end{array}$ \\
\hline Bebek: & - Pembe Fare, Kırmızı Fil nerede? \\
\hline Uygul & - (Uygulayıcı yanıt verir). Ben de bilmi \\
\hline Bebek & - Şimdi ne olacak? \\
\hline
\end{tabular}

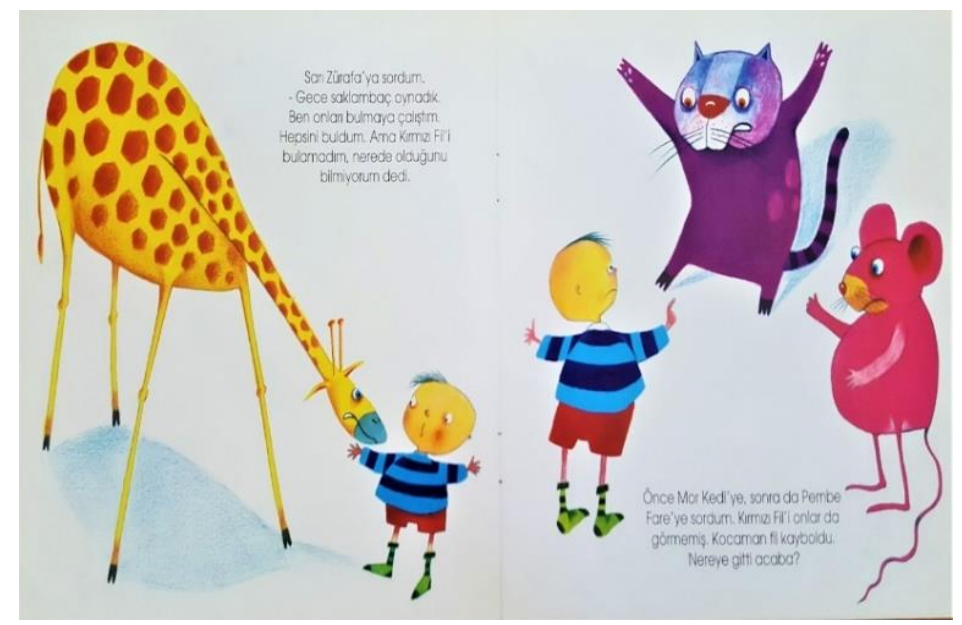

Görsel 6. Kitabın Beşinci Sayfası

Bebek ile uygulayıcı arasında kitabın beşinci sayfasına yönelik olarak gerçekleştirilen konuşmalar incelendiğinde, çocuk karakterin Kırmızı Fil'i bulmak için Sarı Zürafa, Mor Kedi ve Pembe Fare'ye yönelik soru temelli yaklaşımı uygulayıcı tarafından bebeğe sezinletilmiştir. Böylelikle, bebeğin Sarı Zürafa, Mor Kedi ve Pembe Fare'yi yansıtan kavramlarla ilişkisi pekiştirilmeye çalışılmıştır. Bununla birlikte, çocuk ile üç yan karakter arasındaki soru temelli yaklaşımının oluşturduğu merak ve gizem, bebeğin bu duruma yönelik "Şimdi ne olacak?" sorusuyla kendini göstermiştir. Daha açık bir anlatımla, Sarı Zürafa, Mor Kedi ve Pembe Fare'nin Kırmızı Fil'in yerini bilmemesi, bebeğin bu duruma yönelik sorduğu sorularla merak ve gizem duygularını ortaya çıkarmıştır. İşte bebekte oluşan bütün bu duygular, görsellerin kavramsal olarak adlandırılmasıyla belirgin kılınan kurgusal ilişkinin bebek tarafından sezinlenmesiyle gerçekleşmiştir.

\section{Sekizinci Alt Uygulama Evresi}

Sekizinci alt uygulama evresinde, kitabın geri kalan bütün sayfalarına yoğunlaşılarak çocuk karakterin Yeşil Karga'ya yönelik sorularıyla birlikte Kırmızı Fil'in kapıdan içeri girmesinin yarattığı gizemli durumu bebeğin sezinleyebilmesi için aşağıda yer alan konuşma gerçekleştirmiş̧ir:

Uygulayıcı: - (Adı), istesen bir de Yeşil Karga'ya soralım Kırmızı Fil'in nereye gittiğini, olur mu? 
Bebek: $\quad$ - (Çok fazla ilgilenmez). Aaa Kırmızı Fil. İşte orada.

Uygulayıcı: - Aaa. Kırmızı Fil gelmiş.

Bebek: - Kırmızı Fil. Kırmızı Fil.

Uygulayıcı: - Ama çok üzgün görünüyor (Uygulayıcı, Kırmızı Fil gibi üzgün olur).

Bebek: $\quad$ - (Bebek de aynı davranışı yapar). Evet üzgün.

Uygulayıcı: - (Adı), Kırmızı Fil neden üzgün görünüyor?

Bebek: $\quad-$... (Bakma ve inceleme). Diğer sayfayı çevirme.

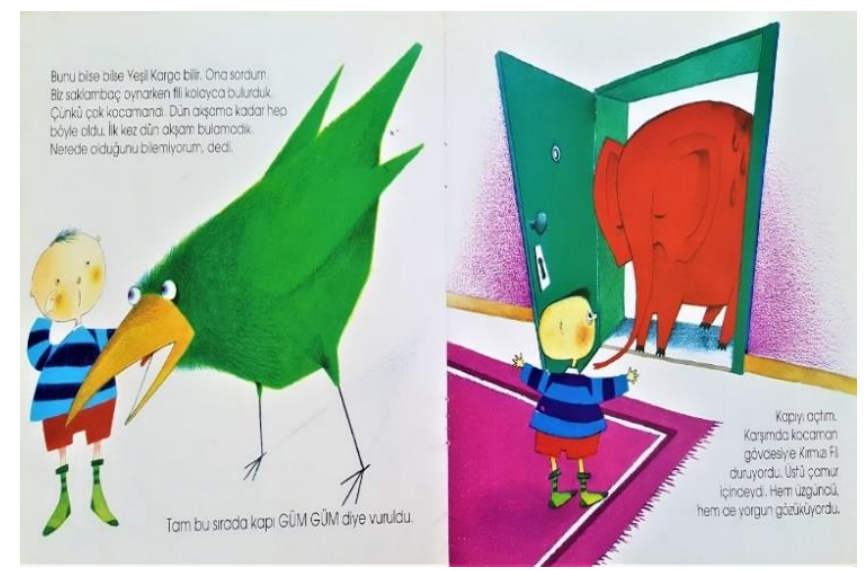

Görsel 7. Kitabın Altıncı Sayfası

Bebek: $\quad$ - (Bakma ve inceleme).

Uygulayıcı: - (Adı), bak çocuk çok mutlu oldu Kırmızı Fil'i görünce. Çocuk, hemen Kırmızı Fil'in hortumuna sarıldı. Sen de sarılmak ister misin?

Bebek: - Hı hı. (Sayfaya sarılır).

Uygulayıcı: - Peki, o da ne? Yerlerde ayak izi var. Baksana (İşaret edilir). Kırmızı Fil, dışarı çıkmış. Ayak izleri bunu gösteriyor. (Adı), Kırmızı Fil'in ayağının izine baksana. Siyah siyah. Parmak izleri de görünüyor.

Bebek: $\quad$-... (Bakma ve inceleme). Ayak izlerine baksana (Uzatarak).

Uygulayıcı: - (Adı), Kırmızı Fil neden üzgün görünüyor?

Bebek: $\quad-. .$. (Bakma ve inceleme).

Uygulayıcı: - (Adı), Kırmızı Fil nereye gidiyor?

Bebek: $\quad$-... (Bakma ve inceleme). Diğer sayfayı çevirme. 


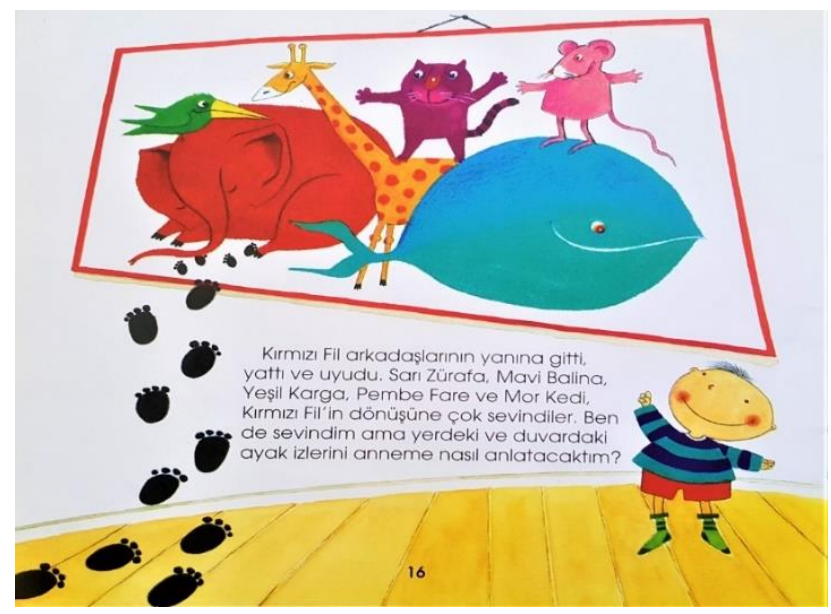

Görsel 8. Kitabın Yedinci Sayfası

Bebek: $\quad$ - ... (Bakma ve inceleme).

Uygulayıcı: - (Adı), Yeşil Karga, Sarı Zürafa, Mor Kedi, Pembe

Fare ve Mavi Balina çok mutlu olmuşlar (Tek tek gösterme).

Bebek: - Evet, çok mutlu olmuşlar.

Uygulayıcı: - Peki, sence Kırmızı Fil de mutlu mu?

Bebek: $\quad$ - ... (Bakma ve inceleme). Gözünü kapatmış.

Uygulayıcı: - O zaman Kırmızı Fil üzgün mü?

Bebek: $\quad-$ Hı hı.

Uygulayıcı: - (Adı), Kırmızı Fil neden üzgün görünüyor?

Bebek: - - (Durma, inceleme ve düşünme).

Uygulayıcı: - (Adı), sence Kırmızı Fil neden üzgün görünüyor?

Bebek: - - (Durma ve bekleme). Annesinden ayrılmış.

Uygulayıcı: - Aferim sana.

Bebek: - Hadi baştan.

Bebek ile uygulayıcı arasında kitabın geri kalan bütün sayfalarına yönelik olarak gerçekleştirilen konuşmalar incelendiğinde, bebeğin Kırmızı Fil’in üzgün bir biçimde ortaya çıkışını duyumsamaya çalışması, onun merakla diğer sayfalara yönelmesine olanak tanımıştır. Çocuk karakterin Kırmızı Fil’i görünce sevinmesi, bebeğin de aynı davranışı sayfa üzerinde gerçekleştirmesini sağlamıştır. Bu durum, bebeğin çocuk karakterle özdeşim kurduğunun da göstergesidir. Bununla birlikte, Kırmızı Fil'in neden ortadan kaybolduğunu ve bir anda neden üzgün bir biçimde geri geldiğini anlamaya çalışan bebeğin, "ayak izleri" kavramını sezinleyince Kırmızı Fil’in dışarı çıktığını görsel metinden duyumsadığı görülüyor. Kırmızı Fil'in tabloda da gözlerinin kapalı olmasından üzgün olduğunu gören bebeğin uygulayıcının sorduğu "Kırmızı Fil neden üzgün görünüyor?" sorusuna "Annesinden ayrılmış." yanıtı, onun görsel metinden edindiği kavramlarla düş kurma ve düşünme sorumluluğu aldığını ortaya koymaktadır. Bütün bu yönleriyle, ilk haftalık sekiz alt uygulama evresinde bebeğin bilmediği "Kırmızı Fil, Mor Kedi, Pembe Fare, Mavi Balina, Sarı Zürafa, Yeşil Karga, var, yok, mutlu, üzgün, küp, gece, gündüz, içinde, üstünde, uykuda, uyanık, eğik, düz, şaşırma, şaşırmama, sandalye, düzelmek, kravat, takmak, atkı, dolamak, bavul" kavramlarını görsellerden yola çıkarak sezinlediği görülmektedir.

\section{İkinci Haftadaki Uygulama Evrelerine Yönelik “Kırmızı Fil’i Gördünüz Mü?” Başlıklı Kitaptan Elde Edilen Bulgular}

Bu bölümde, iki alt uygulama evresiyle bebeğin kitabın tamamına yönelik elde ettiği kavramlar ortaya konan alıntılarla ayrıntılı bir biçimde gösterilmiştir. 


\section{Birinci Alt Uygulama Evresi}

Birinci alt uygulama evresinde, uygulayıcı bebekle birlikte bütün kitabı sonuna kadar okumuş ve ilk uygulama haftasında öğrendiği ve gözden kaçan kavramların sezinletilmesine yönelik aşağıdaki konuşmayı gerçekleştirmiştir:

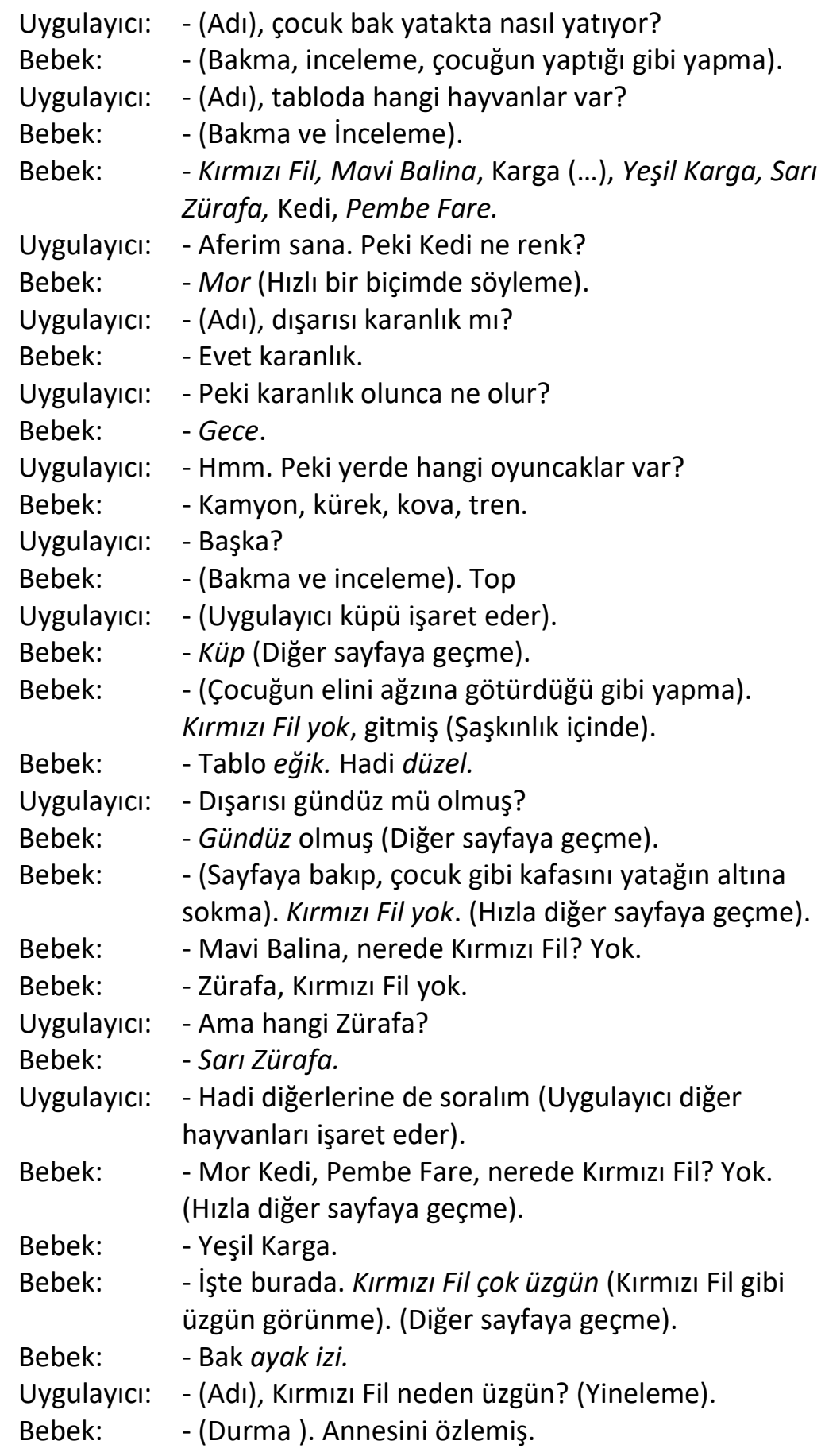

Bebek ile uygulayıcı arasında kitabın geri kalan bütün sayfalarına yönelik olarak gerçekleştirilen konuşmalar incelendiğinde, bebeğin görsellerden edindiği kavramsal birikimle kitabın kurgusal bütünlüğünü çözümlemeye çalıştığı görülmektedir. Bebeğin, ilk haftada kitapla kurduğu ilişkide sezinlediği kavramları "Kırmızı Fil, Mavi Balina, Yeşil Karga, Sarı Zürafa, Mor Kedi, Pembe Fare, eğik, gece, gündüz, küp, düzel, var, yok, ayak izi" ikinci haftada gerçekleştirilen görsel okumada da kullanması, bebeğin bilinçli bir biçimde kavramları kullandığını göstermektedir. Bununla birlikte, bebeğin Kırmızı Fil'in kaybolmasıyla oluşan serüvendeki diğer görsel karakterleri tanıyarak ve onların 
yerine yanıt vererek "Zürafa, Kırmızı Fil yok." kitapta var olan serimi çözümü kavuşturmak istemekte ve bu yüzden hızlı hızlı sayfaları çevirmektedir. Bu durumun, bebeğin kitabın görsellerinden edindiği kavramsal birikimle ortaya çıkan merak ve keşfetme isteğinin bir sonucu olduğu söylenebilir.

\section{ikinci Alt Uygulama Evresi}

İkinci alt uygulama evresinde, uygulayıcı bebekle birlikte yeniden bütün kitabı sonuna kadar okumuş ve birinci alt uygulama evresinde gözden kaçan kavramların sezinletilmesine yönelik aşağıdaki konuşmayı gerçekleştirmiştir:

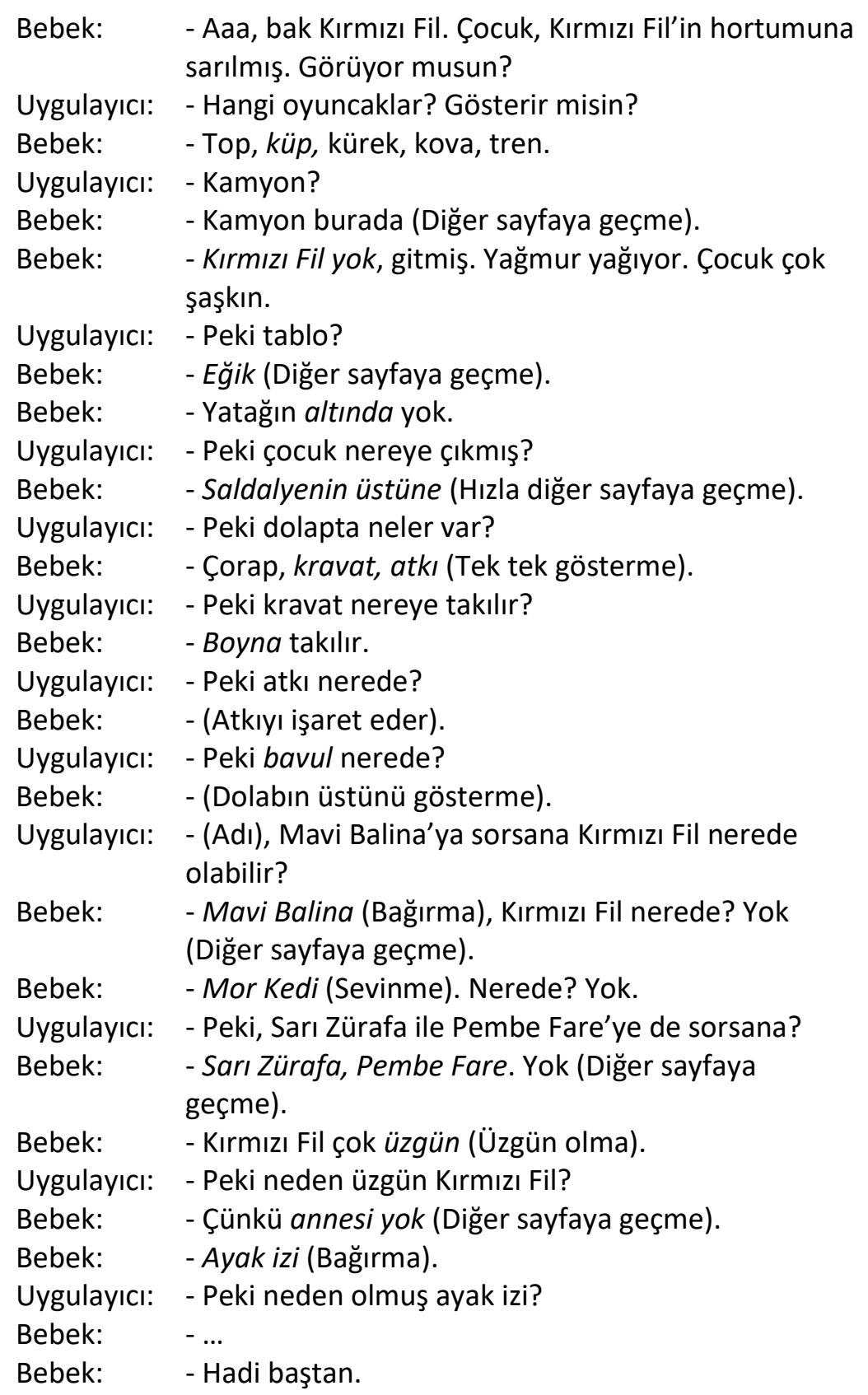

İkinci alt uygulama evresinde, bebek ile uygulayıcı arasında kitabın tamamına yönelik konuşmalar incelendiğinde, bebeğin sezinlediği kavramlardan yola çıkarak kitaba yönelik görsel okuma yaptığı görülmektedir. Daha farklı bir söyleyişle, bebek kitapta yer alan görsellerden sezinlediği kavramlardan yola çıkarak çocuk ile Kırmızı Fil arasında geçen kurgusal ilişkiye ortak olmaya çalışmıştır. Bununla birlikte, bebeğin sezinlediği kavramlar onun kitapta yer alan her bir görseli incelemesine, görseller arasındaki ilişkileri duyumsamasına, farklı karakterleri algılamasına, karakterlerin duygu 
durumları arasındaki benzer ve farklı yönleri görebilmesine, Kırmızı Fil'in neden kaybolduğuyla ilgili olarak kestirimde bulunmasına olanak tanımıştır. Bu durum, bebeğin sezinlediği kavram sayısına bağlı olarak kitaba yönelik anlama ve anlatma sorumluluğu aldığını ortaya koymaktadır. Bebek ile uygulayıcı arasında yukarıda yer alan konuşmalar incelendiğinde, bebeğin birinci alt uygulama evresinde sezinlediği kavramları ikinci alt uygulama evresinde de bilinçli bir biçimde kullandığı görülmektedir.

\section{Tartışma ve Sonuç}

Çocuk edebiyatı yapıtları, çocukların erken dönemden başlayarak dilsel ve görsel öğelerle kavram tasarımı sürecinde yer almasını sağlamalıdır (Sever, 2008, 2013). Çocukların kavram tasarımı sürecinde edindiği sözcüklerle yaşamı algılamaya çalışmalarında, erken dönemden başlayarak karşılaştıkları kitapların nitelikli ve düzeye uygun olması belirleyici birer değişken olmaktadır. Çünkü çocukların ilk yıllardan başlayarak düzenli bir biçimde kavram dağarcıklarının geliştirilmesi, onların anadili becerisine katkı sağladığı gibi aynı zamanda düşünsel süreçlerini de etkili bir biçimde kullanmasına olanak tanır (Sever, 2018). Özellikle çocukların bilişsel gelişiminin üçte ikisini ilk beş yıllık dönemde tamamlaması (Piaget, 2004), bu yaş döneminde kavram tasarımı sürecinin önemini daha çok ortaya koymaktadır. Çünkü kavramların kazanılması çocuğun doğumuyla başlayan bir süreçtir (Senemoğlu, 2011). Bu nedenle, çocuğun kavram dağarcığının erken dönemde düzeye uygun çocuk kitaplarında yer alan görsellerden edindiği bilgilerle genişletilmesi gerekmektedir. Böylelikle, çocuğun düzeye uygun çocuk edebiyatı yapıtlarından edindiği görselleri adlandırması, kavramsal birikimiyle anlama ve anlatma becerilerini geliştirerek yapılandırmasına olanak tanıyacaktır.

$\mathrm{Bu}$ araştırmada, birinci haftadaki alt uygulama evreleri incelendiğinde bebeğin kitaptan "Kırmızı Fil, Mor Kedi, Pembe Fare, Mavi Balina, Sarı Zürafa, Yeşil Karga, var, yok, mutlu, üzgün, küp, gece, gündüz, içinde, üstünde, uykuda, uyanık, eğik, düz, şaşırma, şaşırmama, sandalye, düzelmek, kravat, takmak, atkı, dolamak, bavul" kavramlarını sezinlediği görülmektedir. Daha açık bir söyleyişle, bebeğin yazınsal bir kitapla girdiği iletişim ve etkileşim sonucunda kavram dağarcığının arttığı ve edindiği kavramlara bağlı olarak kitabın kurgusuna yönelik olarak çözümlemelerde bulunduğu gözlemlenmiştir. Bebeğin kitapta yer alan görsellere bakması, incelemesi ve uygulayıcı tarafından verilen adlandırmaları belleğine kodlaması, onun ilgili görseldeki kavramları tanımasına ve daha sonraki görsel okumalarda bu kavramları bilinçli bir biçimde kullanmasına olanak tanımıştır. Özellikle bebeğin birinci haftadaki alt uygulama evrelerinde kitapta görsel olarak sezinletilmeye çalışılan "Kırmızı Fil var/Kırmızı Fil yok, mutlu/üzgün, gece/gündüz, içinde/üstünde, uykuda/uyanık, eğik/düz, şaşırma/şaşırmama" gibi karşıt kavramları duyumsaması, kitabın sayfalarına bağlı olarak farklılaşan kurguyu anlaması ve anlatmasına katkı sağlamıştır. Bebeğin bu evrelerde, görsellerde karşıt bir biçimde yer alan nesne/olay/durum ilişkisini kavramsal olarak anlamaya ve anlatmaya çalışması, onun kavramsal karşıtlıklardan yola çıkarak kitabın kurgusuna ortak olmaya çalıştığını göstermektedir.

Bu araştırmada, ikinci haftadaki alt uygulama evreleri incelendiğinde bebeğin uygulayıcının yinelemelerine gerek duymadan kitabı görsel olarak okuduğu ve ilk haftadaki alt uygulama evrelerinde edindiği kavramları "Kırmızı Fil, Mor Kedi, Pembe Fare, Mavi Balina, Sarı Zürafa, Yeşil Karga, var, yok, mutlu, üzgün, küp, gece, gündüz, içinde, üstünde, uykuda, uyanık, eğik, düz, şaşırma, şaşırmama, sandalye, düzelmek, kravat, takmak, atkı, dolamak, bavul" yeniden kullandığı gözlemlenmiştir. Bu durum, kitabın serim, düğüm ve çözüm bölümlerinde sezinletilmeye çalışılan kurgunun ve karakterlerin bilinçli bir biçimde bebeğin kullandığı kavramlarla yapılandııılığını göstermektedir. Daha açık bir anlatımla, uygulayıcının katkılarıyla bebeğin kitabın kurmaca dünyası içinde Kırmızı Fil ile çocuk karakterin yaşadığı duygusal (üzgün/mutlu, şaşırma/şaşırmama vb.) değişimin ipuçlarını görmesi, karakterlerin fiziksel özelliklerini, olay ve duruma göre sezinletilen davranışlarını ve duygu durumlarını bir anda betimlemesi, görsellerde betimlenen olay ve durumlardaki farklılaşmanın nedenlerini bulup kavramsallaştırması, olay ya da durumları eylem ve adlarla anlatması, her bir sayfadaki görselde sezinletilen olay ya da durumu söylemeye çalışması, bebeğin kavram dağarcı̆ıının artmasını sağlamıştır. Bununla birlikte, bebeğin dil gelişiminin dışarıdan gelen renk, çizgi, söz, sözcük ya da tümce gibi dilsel kodları çözümlediği ve simgenin nesneden farklı olduğunu anladığı bir dönemde (24. ay) olmasından dolayı (Piaget, 2004), onun kitapta yer alan görsellerle kurduğu ilişkinin boyutu daha çok "bakma, 
sezinleme ve anlatma" biçimine taşınmıştır. Bu durum, bebeğin kitapta yer alan görsellerle girdiği etkileşimin bir sonucu olarak kavram dağarcığının daha çok geliştiğini ortaya koymaktadır.

Bu araştırmada, bebeğin kitapla kurduğu ilişkide görsellerde yer alan karakterleri (baş karakter ya da yardımcı karakterler) ve karakterlerin içinde bulunduğu kurgusal ortamı kavramsal yönden anlamaya başladığı görülmüştür. Daha açık bir anlatımla, bebeğin kurgu içindeki karakterin yüzündeki duygu durumunu inceleyerek, olay içindeki davranışına bakarak ya da diğer karakterlerle ilişkisine göre eylemlerini kavramsallaştırmaya çalışması, bebeğin kavram dağarcığının artmasına olanak tanımıştır. Örneğin, kitapta yer alan çocuk karakterin Kırmızı Fil'in tablodan kaybolmasıyla yatağın üstünde şaşkınlık içinde olması ya da üzgün görünmesi, bebeğin de çocuk karakterden yola çıkarak "Kırmızı Fil yok, çocuk şaşırmış, üzgün" söylemlerinin oluşmasına ve her iki karakterin ilgili görsellerde sezinletilmeye çalışılan davranışlarını anlamasına katkı sağlamıştır. Özellikle "Kırmızı Fil nereye gitmiş?" sorusuna bebeğin edindiği kavramlardan yola çıkarak düş kurma ve düşünme sorumluluğuyla kestirimde bulunup sonuçlar üretmiştir (Annesinden ayrılmış, annesini özlemiş ve annesi yok). Bu durum Sever'in (2008) vurguladığı "düş kurma ve düşünme sorumluğu alma" becerilerinin nitelikli ve düzeye uygun çocuk edebiyatı yapıtlarıyla deneysel olarak somutlanabileceğini göstermektedir. Bu bakımdan, erken dönemden başlayarak bebeklerin gelişimsel düzeylerine uygun nitelikli kitaplarla kavram dağarcıkları geliştirilerek onların düş kurma ve düşünme sorumluluğu almalarına olanak tanınmalıdır.

Yeterli bir biçimde kavram dağarcıkları gelişmeyen bebekler daha yavaş gelişim gösterir (Senemoğlu, 2011). Bununla birlikte, nesnelere bakma, onları elleriyle, gözleriyle ve ağızlarıyla araştırma, çevrede özgürce dolaşma olanağından yoksun kalan bebeklerin kavramsal, algısal ve motor becerilerinde gerileme görülür (Gander ve Gardiner, 2010). Bu nedenle, duyuları devindiren ve beyni algılama sürecine yönelten uyaranların bebeklik evresinden başlayarak çocukların yaşamına girmesi gerekir (Sever, 2018). İşte, erken dönemden başlayarak bebeğin kavramsal olarak önemli yaşantılar edinmesini sağlayacak düzeye uygun nitelikli kitaplarla etkileşiminin sağlanması gerekmektedir. Bu etkileşiminin sağlanması için ise, anne ve babanın hem düzeye uygun öğretici ve yazınsal kitap konusunda bilinçli olması hem de bu kitapların görsel bir biçimde okunmasında kılavuz olma sorumluluğunun farkında olması gerekir. Daha farklı bir anlatımla, bebeğin, anne ve babanın katkısıyla düzenli olarak görsel ve dilsel bir uyaran olan kitaplarla etkileşim içinde olması, onun algılama becerilerini devindirerek renk, çizgi ve sözcüklerin oluşturduğu anlam evrenine ortak olmaya çalışmasına olanak tanıyacaktır. Anne-baba ile birlikte bebeğin kitaplarla etkileşiminin sürekli kılınması durumunda ise, bebeğin görsellerde yer alan nesneleri ve karakterleri ya da karakterlerin olay ve durumlar içindeki duygu ve düşüncelerini anlamlandırarak kavramsal dağarcığını yavaş yavaş yapılandırabilecektir. Bu bakımdan, bebeğin kavramsal gelişiminde anne ve babanın katılımıyla sosyal bir etkileşim ortamına dönüşen düzeye uygun nitelikli kitaplarla oluşturulan yaşantıların önemli olduğu söylenebilir.

Sonuç olarak, bu araştırmada uygulayıcının kılavuzluğunda bebeğin düzeye uygun nitelikli bir kitaba yönelik görsel okuma yapması, onun kavram dağarcığının artmasına olanak tanımıştır. Bu araştırmadan yola çıkarak sunulacak öneri ise, farklı yaş gruplarında cinsiyet ya da sosyo-ekonomik düzey gibi farklılıklar göz önünde bulundurularak bebeklerin düzeye uygun nitelikli kitaplarla kavram dağarcıklarının ne kadar gelişip gelişmediğini ortaya koyan deneysel araştırmaların yapılmasıdır.

\section{Kaynaklar}

Ak, B. (2011). Uyurgezer Fil. İstanbul: Can Çocuk Yayınları.

Avcı, F. (2010). Kırmızı Fil'i gördünüz mü? İstanbul: Can Çocuk Yayınları.

Avcı, F. (2014). Benim minik kırmızı balığım. İzmir: Tudem Yayıncılık.

Bakırcıoğlu, R. (2012). Ansiklopedik eğitim ve psikoloji sözlüğü. Ankara: Anı Yayıncılık.

Bee, H. ve Boyd, D. (2009). Çocuk gelişim psikolojisi. İstanbul: Kaknüs Yayınları.

Cook, T. D. ve Campbell, D. T. (1979). Quasi-experimentation: Design and analysis issues for field settings. Boston: Houghton Mifflin Company.

Dilidüzgün, S. (2004). Çağdaş çocuk yazını. İstanbul: Morpa Yayınları.

Gander, M. J. \& Gardiner, H. W. (2010). Çocuk ve ergen gelişimi. Ankara: İmge Yayınevi. 
Miller, P. H. (2008). Gelişim psikolojisi kuramları. Ankara: İmge Kitapevi.

Norton, D. E. ve Norton, S. E. (2010). Through the eyes of a child: An introduction to children's literature. New York: Pearson.

Piaget, J. (2004). Çocukta zihinsel gelişim. İstanbul: Cem Yayınları.

Senemoğlu, N. (2011). Gelişim, öğrenme ve öğretim. Kuramdan uygulamaya. Ankara: PegemA Yayıncılık.

Sever, S. (1995). Çocuk Kitaplarında Bulunması Gereken Yapısal ve Eğitsel Özellikler. Abece Dergisi, 107, 14-15.

Sever, S. (2008). Çocuk ve edebiyat. İzmir: Tudem Yayınları.

Sever, S. (2013). Çocuk edebiyatı ve okuma kültürü. İzmir: Tudem Yayınları.

Sever, S. (2018). Sanatsal uyaranlarla dil öğretimi. İzmir: Tudem Yayınları.

Striker, S. (2005). Çocuklarda sanat eğitimi. İstanbul: Epsilon Yayınevi.

Tekin, E. (2000). Karşıllaştırmalı tek-denekli araştırma modelleri. Özel Eğitim Dergisi, 2(4), 1-12.

Tekin-iftar, E. (2018). Eğitim ve davranış bilimlerinde tek-denekli araştırmalar. E. Tekin-iftar (Ed.), A-B modelleri (ss. 155-177). Ankara: Anı Yayıncılık.

Tepebaş, G. Ş. ve Haktanır, G. (2013). 6 yaş çocuklarının temel kavram bilgi düzeylerini desteklemeye yönelik öyküleştirme yöntemine dayalı bir eğitim uygulaması. Eğitim ve Bilim, 38(169), 62-79.

Türkiye Bilimler Akademisi (2011). Türkçe bilim terimleri sözlügü. Sosyal bilimler. Ankara: TUBA.

Yavuzer, H. (2012). Bedensel, zihinsel ve sosyal gelişimiyle çocuğunuzun ilk 6 yılı. İstanbul: Remzi Kitabevi.

Yazar, (2019). Nitelikli çocuk edebiyatı yapıtlarıyla 0-24 aylık dönemde olan bir bebeğin kavram bilgisinin geliştirilmesi. Prof. Dr. Sedat Sever'e Armağan-Türkçe Eğitimi ve Çocuk Edebiyatı Kurultayı (25-26 Nisan 2019). Kurultay Kitabı (ss. 197-293). Ankara: Ankara Üniversitesi Yayınları No: 645.

Yıldııı, A. ve Şimşek, H. (2005). Sosyal bilimlerde nitel araştırma yöntemleri. Ankara: Seçkin Yayıncılık. Yörükoğlu, A. (2010). Çocuk ruh sağlığı. Çocuğun kişilik gelişsimi eğitimi ve ruhsal sorunları. İstanbul: Özgür Yayıncılık.

\section{Introduction}

\section{Extended Abstract}

The purpose of this study is to examine the effect of a level-appropriate children's book on the development of concept vocabulary. This situation can reveal the effects of level-appropriate works of children's literature on the concept vocabulary. Searching for an answer to a similar problem in the research process may empirically reveal the impact of children's literature works in the development of conceptual vocabulary in a more concrete way. This may show educators, experts, parents the importance of conceptualization of children's books prepared in the early period. Shortly, since children's literature is the first tools that connect children with qualified books from an early period and introduce them the beauties of their mother tongue, the conceptual knowledge of the child should be supported by visuals created with color and line. Because the child can expand the boundaries of a language and conceptual repertory by looking at these visuals that contribute to their conceptual development. In particular, the lack of cognitive skills that the child can acquire linguistic symbols in early period is a major responsibility for the concept. Then, conscious efforts of parents, and giving visual names to linguistic names enable the child to express the concepts in the world of meaning verbally. With a simple saying, color and line expanding the child's universe of meaning find their expression in words. Therefore, early children's literature works are vital for the development of a child's vocabulary.

\section{Method}

This is a single-subject study examining the effect of a level-appropriate child's book in the development of conceptual vocabulary. In this respect, the time series model (the ABAB model) (Cook \& Campbell, 1979), which is one of the single-subject research designs was applied in this study. The $A B A B$ model is realized by measuring the level of onset and repeating the procedures in the $A B$ model 
where the experimental procedure is performed. The participant of this study was the infant of the researcher who is two years old. The reason for the researcher to include his child in the research process was that it was difficult to find a two-year-old participant who can observe the effect of levelappropriate children's books in the development of the conceptual vocabulary, which would last approximately two weeks and could be applied at regular intervals. In this study, how a two-year-old infant structured the concept design process with qualified children's literature works was shown with the $A B A B$ model. In a previous study, the number of concepts which could be recorded by an observation as a result of the interaction of the infant with instructional and literary books in the 0-24 months period was recorded as 1053. In other words, the number of concepts acquired by the infant during the 0-24-month period was determined as the beginner level. After determining the basic level, the practitioner performed the experimental process with 8 sub-application phases during the first week of the first application process, in order to show how a suitable book structured the concept design process of the infant. After this, the practitioner re-read the book presented to the infant in the previous application phase with 2 sub-application phases that would last for one week and re-recorded the concepts acquired by the infant during the concept design process. Implementation of this research was carried out in a home environment which allowed the child to play freely and comfortably. In the 24th month, stimuli such as toys, television and telephone distracting the children during the application process while the child interacted with the books were removed. While the visuals in the book determined during the application process of this research were shown to the infant, the practitioner tried to explain the books to the infant by explaining the visuals with sound and motion. In this process, the practitioner used mystery and intriguing utterance features to allow the infant to sense the fiction on the pages of each book.

\section{Result and Discussion}

It was observed that the infant begins to understand the characters in the visuals and the fictional environment in which the characters are located conceptually in this research. More clearly, the infant's ability to examine the emotion on the face of the character in the fiction, to look at his behavior in the event or to conceptualize his actions according to his relationship with other characters enabled the infant's conceptual vocabulary to increase. For example, the child's character in the book, the Red Elephant disappeared from the table to be surprised or upset on the bed, looking at the child's character, "Red Elephant, child surprised, sad" discourse to occur and both characters tried to be sensed in the relevant visuals understanding. Especially for "Where did the Red Elephant go?" question, with the competence of dreaming and thinking based on the concepts acquired by the infant, he made predictions and produced results (separated from his mother, he misses her). This showed that the skills of dreaming and taking responsibility for thinking can be embodied experimentally with level appropriate children's literature works. In this regard, starting from an early period, babies should be offered an opportunity to take responsibility for dreaming and thinking by developing conceptual vocabulary with books suitable for their developmental level.

Infants who did not develop adequate conceptual vocabulary developed more slowly. However, there was a decline in the conceptual, perceptual and motor skills of infants who were deprived of the ability to look at objects, touch them with their hands, eyes and mouths, and move around freely. For this reason, stimuli that stimulated senses and that directed the brain to the perception process had better be introduced to children starting from infancy. Here, starting from an early period, it is necessary to ensure that the infant interacts with level-appropriate books which will enable them to acquire conceptually important experiences. In order to achieve this interaction, both parents should be aware of the level-appropriate instructional and literary books and be aware of the responsibility of guiding them in the visual reading of these books. In other words, the infant's regular interaction with the books as a visual and linguistic stimulus with the contribution of the mother and father will enable him to associate with the repertory of concept formed by color, lines and words. If the interaction between the parents and the infant is maintained, the infant will gradually contribute to his/her conceptual repertory by understanding the objects and characters in the visuals or the feelings and thoughts of the characters in the events and situations. In this respect, it can be said that 
the experiences created with level-appropriate books that are transformed into a social interaction environment with the participation of parents are important in the conceptual development of the infant.

As a result of the research, the visual reading of the infant for a level-appropriate book in the guideline of the practitioner allowed him to increase his conceptual vocabulary. Based on this research, it is suggested to conduct experimental research showing the development of conceptual vocabulary of babies with level-appropriate books considering the differences such as gender or socio-economic level in different age groups. 